Pandemics: Implications for Research and Practice in Industrial and Organizational Psychology

$\begin{array}{ccc} & \text { Cort W. Rudolph } & \\ \text { Saint Louis University } & \\ \text { Blake Allan } & \text { Malissa Clark } & \text { Guido Hertel } \\ \text { Purdue University } & \text { University of Georgia } & \text { University of Münster } \\ \text { Andreas Hirschi } & \text { Florian Kunze } & \text { Kristen Shockley } \\ \text { University of Bern } & \text { University of Konstanz } & \text { University of Georgia } \\ \text { Mindy Shoss } & \text { Sabine Sonnentag } & \text { Hannes Zacher } \\ \text { University of Central Florida } & \text { University of Mannheim } & \text { Leipzig University } \\ & & \end{array}$

Rudolph, C.W., Allan, B., Clark, M., Hertel, G., Hirschi, A., Kunze, F., Shockley, K., Shoss, M., Sonnentag, S., \& Zacher, H. (2020). Pandemics: Implications for Research and Practice in Industrial and Organizational Psychology. Industrial and Organizational Psychology: Perspectives on Science and Practice.

Author Note

Cort W. Rudolph, Department of Psychology, Saint Louis University, St. Louis, MO, USA. Blake Allan, College of Education, Purdue University, West Lafayette, IN, USA. Malissa Clark, Department of Psychology, University of Georgia, Athens, GA, USA. Guido Hertel, Department of Psychology, University of Münster, Münster, Germany. Andreas Hirschi, Department of Work and Organizational Psychology, University of Bern, Bern, Switzerland. Florian Kunze, Chair for Organisational Studies, University of Konstanz, Konstanz, Germany. Kristen Shockley, Department of Psychology, University of Georgia, Athens, GA, USA. Mindy Shoss, Department of Psychology, University of Central Florida, Orlando, FL, USA. Sabine Sonnentag, Department of Psychology, University of Mannheim, Mannheim, Germany. Hannes Zacher, Institute of Psychology - Wilhelm Wundt, Leipzig University, Leipzig, Germany.

Correspondence concerning this article may be addressed to Cort W. Rudolph, Department of Psychology, Saint Louis University, Saint Louis MO, USA, e-mail: cort.rudolph@health.slu.edu

Mindy Shoss' contribution to this publication was supported by grant number T42OH008438, funded by the National Institute Occupational Safety and Health (NIOSH) under the Centers for Disease Control and Prevention (CDC). Its contents are solely the responsibility of the authors and do not necessarily represent the official views of the NIOSH or CDC or the Department of Health and Human Services.

Author order was determined alphabetically (excluding the first author). 


\begin{abstract}
Pandemics have historically shaped the world of work in various ways. With COVID-19 presenting as a global pandemic, there is much speculation about the impact that this crisis will have for the future of work and for people working in organizations. In this article, we discuss 10 of the most relevant research and practice topics in the field of industrial and organizational (IO) psychology that will likely be impacted by COVID-19. For each of these topics, the pandemic crisis is creating new work-related challenges, but also presenting various opportunities. The topics discussed herein include occupational health and safety, work-family issues, telecommuting, virtual teamwork, job insecurity, precarious work, leadership, human resources policy, the aging workforce, and careers. This article sets the stage for further discussion of various ways in which IO psychology research and practice can address the impacts of COVID19 for work and organizational processes that are affecting workers now and will shape the future of work and organizations in both the short and long term. This article concludes by inviting IO psychology researchers and practitioners to address the challenges and opportunities of COVID-19 head-on by proactively innovating the work that we do in support of workers, organizations, and society as a whole.

Keywords: Pandemic; Crisis; Novel Coronavirus; COVID-19; SARS-CoV-2
\end{abstract}


Pandemics: Implications for Research and Practice in Industrial and Organizational Psychology Throughout human history, pandemics have shaped how work is understood, carried out, and organized. For example, historians have suggested that following the Black Plague in 1350, laws and attitudes regarding labor and compensation changed across Western Europe (Cohn, 2007). Similarly, in the midst of the 1918 flu pandemic, which disproportionately affected working-age adults, labor uprisings in the United States resulted in hundreds of thousands of workers walking off their jobs in protest of working conditions (Freeman, 2020; Clay, 2020). Following the 1918 pandemic, workers saw improvements in health and safety protections, including the advent of employer-sponsored health insurance schemes (Spinney, 2020). More recently, the SARS pandemic of 2003 had demonstrable impacts on the health and well-being of essential workers in "systems relevant" occupations, with between $18 \%$ and $57 \%$ of frontline health care workers reporting experiencing high-levels of emotional distress while managing this crisis (Maunder et al., 2006).

Since the World Health Organization (WHO, 2020) declared the novel coronavirus COVID-19 as a global pandemic crisis on March 11, 2020, there have been over 4.2 million confirmed cases of COVID-19 in 177 countries (approximately one-third or 33\% of confirmed cases have occurred in the United States alone), and over 289,000 associated deaths, worldwide (n.b., statistics as of May 12, 2020; see Wu et al., 2020). Apart from immediate health consequences and mortality, it is still too soon to know the scope of the psychological, social, economic, and cultural impact of COVID-19. However, like with the historical examples offered above, there are already tangible global impacts of COVID-19 on work-related processes. In the United States, jobless rates have skyrocketed to levels never before seen, with 3.3 million new unemployment claims posted in the week of March 23, 2020 alone, which doubled to 6.6 million 
the following week, up to a total of 16.78 million total claims in the week of April $6^{\text {th }}$ (n.b., the highest rate of new claims ever previously recorded was 695,000 in October 1982; Cox, 2020a,b). As of May $7^{\text {th }}, 1$ in 5 American workers had filed for unemployment benefits (totaling approximately 33.5 million claims over seven weeks; Tappe, 2020).

Similar patterns have been observed globally, however buffered to some extent by more proactive and progressive state-supported social and economic policies. For example, as of March $3^{\text {rd }}$, one million job losses were reported across European Union member states (Zsiros, 2020). Economic projections suggest that unemployment across the European Union is expected to rise to $9 \%$ in 2020 . Among member states, Greece and Spain are expected to experience the highest unemployment rates (19.90\% and $18.90 \%$, respectively), whereas Germany is expected to experience the lowest unemployment rate (4\%). To address such concerns, the European Central Bank announced over $€ 870$ billion in economic stimulus programs, an amount equivalent to $7.3 \%$ of the Eurozone GDP (Lagarde, 2020). In Germany, economic projections suggest that as many as three million people's employment could be displaced as a result of this crisis (Escrit, 2020), while nearly 500 thousand employers have applied for government subsidized Kurzarbeit or "short-time work" funds to cover losses of income associated with reduced working hours (Schmitz, 2020). Asia has been particularly affected as well; for example, China's exports have dropped drastically since the virus' inception (Wong, 2020). Moreover, a United Nations report suggests that as many as 400 million workers in India, an economy that is highly dependent on informal work arrangements, will be displaced by the pandemic crisis (Thomas, 2020). Broader but related system challenges have also been noted (e.g., lack of medical resources and supplies; Jacobs, Richtel, \& Baker, 2020), and speculated about (e.g., hindrances to food supply chains; Splitter, 2020). 
Clearly, the COVID-19 pandemic crisis presents a number of tangible challenges, including imposing various psychological consequences upon individuals (see Van Bavel et al., 2020). Such challenges have particular bearing on our understanding of various work-related processes. For example, people are experiencing increased work and family demands, especially as they navigate the need to re-balance multiple roles across work with personal lives. For many, mass work from home policies have already blurred this distinction. Various external demands are likewise increasing, for example, experiencing increased uncertainty, particularly around job security, and financial difficulties. Consistently, a recent study conducted in New Zealand found that a nationwide lockdown resulted in higher rates of mental distress (Sibley et al., 2020). Workers may likewise face paradoxes in how their work is organized, such as experiencing increased workloads in some respects, while simultaneously managing the experience of boredom and idle time, and perhaps low workloads in others. At the same time that such demands and challenges are emerging, this crisis also presents a number of opportunities, especially considering various resources that can be afforded by work organizations to support employees now, and possibly into the future. For example, these opportunities may include potentials for increased social and organizational support from leadership, digitization of work processes, implementation of more effective teamwork, and changes to policies around health management.

Industrial and organizational (IO) psychology is uniquely positioned to provide guidance about how COVID-19 and potential future pandemics will likely impact upon work and people in organizations, by providing evidence-based advice for navigating the challenges and opportunities of such crises. Such guidance comes in the form of both research and practical implications. In this focal article, we discuss 10 of the most relevant areas of research and 
practice that are likely to be impacted by COVID-19 and potential future pandemics: These 10 topics include: 1. Occupational health and safety, 2. Work-family issues, 3. Telecommuting, 4. Virtual teamwork, 5. Job insecurity, 6. Precarious work, 7. Leadership, 8. Human resources policy, 9. The aging workforce, and 10. Careers.

We chose to focus on these 10 areas for two reasons: First, over the past two months, each of these areas has been variously implicated as "central" to the impacts that the COVID-19 pandemic has had and will continue to have on work-related processes. For example, we have already seen evidence for each of these areas discussed in the media surrounding the influence of this pandemic crisis on work. To give a sense of this, Table 1 provides a summary of these 10 areas, examples of the various "sub-topics" that are subsumed within each, and also highlights prototypical media headlines that embody how the COVID-19 pandemic has been impacted by or is impacting work-related processes in each area.

Second, both challenges and opportunities surrounding these 10 areas are likely to have long-term effects on how work is understood, carried out, and organized. Given their centrality to a wide variety of work-related processes, these are also the areas that are likely to be impacted in the case of future pandemic crises, and that have a specific bearing on both research and practice in IO psychology. To this end, Table 2 summarizes example research and practice challenges and opportunities that COVID-19 presents for each area. To be clear, we by no means consider these 10 areas to be inclusive of all of the various ways in which work has been or will be impacted by COVID-19, or any future pandemic crisis. However, we see these areas as those that would be most generally applicable to the study of any pandemic's influence on work behavior, broadly defined. We hope that commentaries on this focal article will offer additional 
ideas for how work will change and be variously impacted as a result of this and future pandemic crises.

With a clearer sense of the motivation of this article, our attention now turns to a discussion of these 10 topics. We then conclude with a high-level summary of this discussion, and a challenge to IO psychologists to address these issues in their research and practice.

\section{Occupational Health and Safety}

The COVID-19 pandemic crisis is highly relevant for occupational health and safety. In general, research and practice activities within this field address topics related to the prevention of health risks at work and to the promotion of employee health, safety, and well-being. The psychological perspective on occupational health and safety focuses on factors in the work environment that may limit employee strain reactions, as well as those that may harm (versus protect) the quality of working life. Harmful factors are usually called "job stressors" or "job demands," and protective factors are often summarized under the umbrella term of "job resources."

The ongoing pandemic crisis impacts occupational health and safety in many respects, although the degree of impact differs largely between occupational groups. For instance, it is important to differentiate between health care workers, people working in other jobs highly needed during the crisis, and persons starting to work from home. In addition, persons who are laid-off or are facing furloughs or reduced working hours are highly impacted by the pandemic crisis because they are threatened by unemployment and increased job insecurity (see also Blustein et al., 2020).

Health care workers, particularly those in frontline jobs working with (possibly infected) patients, face a very high level of job stressors and associated strain symptoms during the crisis 
(see Adams \& Walls, 2020). Although empirical evidence on the occupational health consequences of the COVID-19 pandemic crisis is still limited (Lai et al., 2020; Zhu et al., 2020), research on earlier infectious disease outbreaks (e.g., the SARS outbreak in 2002/2003 and the MERS outbreak in 2015) suggests that health care workers' strain experiences are greatly impacted by crisis, with nurses and employees working in high-risk environment being particularly affected (Brooks, Dunn, Amlôt, Rubin, \& Greenberg, 2018; Lee, Kang, Cho, Kim, \& Park, 2018).

Working in health care during a pandemic crisis must be seen as a "critical incident" with a high emotional impact on employees that may exceed their abilities to cope with the ongoing demands (De Boer et al., 2011; Restubog, Ocampo, \& Wang, 2020). Typical job stressors present during such a crisis include high workloads, hazardous work environments, unclear job instructions, and ambiguous infection control policies, as well as being blamed for mistakes and having to handle coworkers' negative emotions (Tam, Pang, Lam, \& Chiu, 2004). Not surprisingly, fears of being infected are wide-spread and positively associated with feelings of distress (Wong et al., 2005; Zhu et al., 2020). Lack of adequate protection and low perceived organizational support are associated with strain symptoms and with concerns for one's personal and family health (Maunder et al., 2006; Nickell et al., 2004). Moreover, daily work becomes particularly tense when the allocation of treatment resources becomes constrained because not enough resources are available for the number of patients who would need them (Wright, Meyer, Reay, \& Staggs, 2020).

Working under highly stressful and unsafe conditions during a pandemic crisis may not only have immediate negative impacts on health care workers' mental health and well-being, but may develop into longer-term impairments as well, including post-traumatic stress symptoms 
(Maunder et al., 2006; McAlonan et al., 2007).

Although a pandemic crisis puts a particularly heavy burden on the health care sector, health and safety issues are affected in many other jobs as well. Jobs in businesses that continue to provide service to the public (e.g., grocery clerks, drivers, distribution center employees, and employees working in the food-delivery business), as well as managerial and administrative staff in public and private organizations that need to adjust their operations to the ongoing crisis are also facing highly stressful times. Although employees working in these types of jobs during the crisis have not yet received much research attention, one can assume that they are experiencing a high workload, increased infection risk, and high job ambiguity.

Overall, employees working from home during a pandemic crisis seem to be better off because often they do not face increased infection risks and because they have a high discretion about how and when to do their work. Employees who do not usually work from home, however, may lack the adequate space, equipment, and materials to do their work in this unusual setting. Moreover, they may find it difficult to structure their workdays. Because working from home often implies a higher level of autonomy, strain symptoms such as exhaustion may be lower, but social isolation may increase and coworker relationship quality may suffer (Allen, Golden, \& Shockley, 2015; see also the section on telecommuting).

Although some knowledge exists about how a pandemic crisis may impact occupational health and safety (Brooks et al., 2018), more research in this area is needed. It will be important to examine job stress as well as health and safety issues not only in the health-care sector but also in other businesses and industries that face particularly stressful conditions during the pandemic crisis (e.g., grocery stores, transportation and logistics firms). 
First, research on employee health and safety during a pandemic crisis should not only examine the factors that make work stressful, but should also address resources that may help to alleviate the negative effect of the high-stress situation. For instance, researchers may build on a general model such as the job-demands-resources model (Bakker, Demerouti, \& Sanz-Vergel, 2014) and may want to examine both organizational factors such as safety climate and good organizational communication strategies (Moore et al., 2005) as well as individual prerequisites such as adequate levels of training and the availability of specific coping strategies (Maunder et al., 2006; Wong et al., 2005). Research done in extreme work environments such as the military or bushfire brigades might contribute to a better understanding of the strategies that are important for coping with extremely stressful situations (Nassif, Start, Toblin, \& Adler, 2019). Moreover, from a practical perspective, it is highly important to examine which interventions can be used to reduce post-traumatic symptoms in employees who have been exposed to traumatic situations during the pandemic crisis. Again, approaches used in other extreme environments could provide useful insights (Adler, Bliese, McGurk, Hoge, \& Castro, 2011).

Second, working during a pandemic crisis is associated with high strain levels, particularly in employees in the health-care sector and other frontline workers. These high strain levels are not only unfortunate, but may impair daily functioning at work (Bakker \& Costa, 2014), which might lead to inefficiencies and risky behaviors. For instance, research has shown that hand hygiene in hospitals gets neglected during long shifts and when the time between shifts is short (Dai, Milkman, Hofmann, \& Staats, 2015). Therefore, it is important that research identifies factors that help employees function well - even when experiencing high strain levels.

Third, when studying occupational health and safety, the dynamic nature of the pandemic crisis has to be taken into account. Most probably, stress experiences differ largely between 
preparatory and high-crisis states. Accordingly, reductions of stressors (e.g., high workload) might not be feasible during high-crisis states and resources might change their effectiveness as the severity of the situation increases. From a research perspective, the timing of measurements needs a lot of attention. At the same time, the dynamic characteristics of a pandemic crisis offers the opportunity to study temporal aspects of job stress at a more detailed level than can be done in most other settings (Sonnentag, Pundt, \& Albrecht, 2014). Empirical studies additionally could take into account objective crisis indicators in specific regions at specific points of time (e.g., number of infectious cases, administrative regulations at the country or regional level) and relate these objective crisis indicators to strain indicators (e.g., anxiety, fatigue).

Fourth, researchers should strive to implement strong research designs, such as longitudinal data collection and approaches that help to overcome the endogeneity problem (Bliese, Schepker, Essman, \& Ployhart, 2020). Until now, most occupational-health research on infectious disease outbreaks is cross-sectional in nature and uses exclusively self-report measures. On the one hand, such a research strategy is understandable because data collection has to be started quickly - often with very limited financial resources, on the other hand, such designs allow only very limited insight into causal processes. Accordingly, researchers should try to implement more powerful research designs. One possibility would be to use ongoing longitudinal data-collection efforts that have been started before the disease outbreak and to incorporate additional measurement waves that address the emerging crisis situation. Moreover, it has to be taken into account that research participation might be difficult for people working in a crisis mode. Here, innovative approaches are needed, for example, one might think of collecting extremely short yet validated measures, or of integrating data collection into intervention approaches that aim at improving coping support. 
In terms of practical recommendations, Brooks et al. (2018) summarized important implications resulting from research evidence gathered during the SARS crisis. These implications include the provision of adequate training about infection control, building team cohesion and social support, enhancing communication strategies, preparation for negative experiences, and the development of adequate coping strategies. Thus, self-care, team care, and increased awareness about the need to be resilient is particularly important (Adler et al., 2017; Cleary, Kornhaber, Thapa, West, \& Visentin, 2018).

\section{Work-Family Issues}

The COVID-19 pandemic crisis has influenced the work-family interface in a variety of ways, as many recent popular press articles have highlighted (e.g., Friedman \& Westring, 2020; Petersen, 2020). The majority of attention has focused on the topic of work-family conflict, defined as interrole conflict in which the demands of work and family are incompatible in some way (Greenhaus \& Beutell, 1985). Unfortunately, little is known about work and family dynamics specifically during crisis situations (Eby, Mitchell, \& Zimmerman, 2016).

Despite the lack of research in this area, there are several reasons to expect elevated levels of work-family conflict during this pandemic crisis; particularly time-based conflict, when time spent in one domain hinders performance in another, and strain-based conflict, when strains (e.g., tension, anxiety) experienced in one domain negatively impact performance in another domain (Carlson, Kacmar, \& Williams, 2000). With many schools and childcare facilities closed, parents are faced with additional responsibilities caring for and/or homeschooling children during the workday. Time-based conflict is therefore likely to increase because many individuals are spending their traditional "work hours" on paid work while simultaneously caring for children. Strain-based conflict is also likely to be elevated during COVID-19 because individuals 
are experiencing heightened psychological distress and anxiety in general, coupled with increased anxiety and stress about meeting the unique demands posed by work and family.

Researchers could also explore additional types of work-family conflict that may be particularly relevant during this time. Energy-based conflict, defined as when physical exhaustion experienced in one role reduces performance in another role (Greenhaus, Allen, \& Spector, 2006), may be much higher than typical for health care workers working in overflowing emergency rooms or for overextended working parents caring for young children. Cognitivebased conflict involves reduced performance due to preoccupation with another role (Ezzedeen \& Swiercz, 2007), and may be elevated during this time as individuals worry about the impact of the pandemic crisis on their families. Experience sampling and qualitative studies could be implemented to examine specific episodes of work-family conflict (Shockley \& Allen, 2015), which can provide a more complete picture of how the pandemic crisis is impacting individuals' day-to-day lives.

Individuals' work-family challenges will depend on their unique situation (Agars \& French, 2016). During the COVID-19 pandemic crisis, scholars are encouraged to recruit nontraditional samples to better understand the struggles of underrepresented populations in workfamily research. For instance, low income workers are more likely to hold jobs where working from home is not an option (as well as other front-line workers, such as health care workers). As a result, these workers face additional stressors such as how to ensure their own and family members health and well-being given their increased exposure to the virus. Single parents, who already report higher levels of work-family conflict than married parents in general (Byron, 2005), now face even more daunting challenges managing work and family responsibilities during a pandemic crisis. Social capital — support from friends, family, or neighbors — has been 
identified as a critical resource for single parents (Freistadt \& Strohschein, 2013). Unfortunately, this resource may no longer be available to single parents because of physical distancing guidelines. These are just a few of the unique challenges facing underrepresented populations that deserve further study.

The COVID-19 pandemic crisis is a significant life event that has the potential to fundamentally shift a couple's work-family dynamics. In what Lewis (2020) calls "a disaster for feminism," some scholars predict couples will shift towards more traditional gender roles as a result of the pandemic crisis. Indeed, time use data collected from dual-earner couples has revealed such a shift, with gender disparities in men's and women's total workload emerging only after couples transitioned to parenthood (Yavorsky, Kamp Dush, \& Schoppe-Sullivan, 2015). Importantly, self-reported time spent on these activities did not reveal any significant differences, suggesting gender inequalities in shifting workloads may not even be apparent to individuals. In light of these findings, organizational scholars should consider alternative methodologies such as time use data to complement self-reports of work-family dynamics during the COVID-19 pandemic crisis.

There are several practical implications of the COVID-19 pandemic crisis for the workfamily interface. At a national level, the COVID-19 pandemic crisis has exposed stark crosscultural differences in paid family leave policies (see also Guan, Deng, \& Zhou, 2020). For example, the United States is the only industrialized nation with no federal paid family leave policy. During this pandemic crisis, many workers (and, disproportionately, low income workers) are completely reliant on their employer to offer paid leave in the event that they or a family member fall ill due to the virus (n.b., even with the passage of the Families First Coronavirus Response Act, millions of workers in the United States are still not eligible for paid 
leave). Cross-cultural analyses of the impact of paid leave on family adaptation through the pandemic crisis can be used to advocate for additional policies to protect workers. Organizations can help reduce employees' work-family conflict through fostering family-friendly culture norms and attitudes that are broad in scope (French, Dumani, Allen, \& Shockley, 2018). Supervisors can advocate for additional tangible resources that can be used by employees to directly to mitigate stressors and strains (i.e., instrumental support). Both informal and formal forms of support may be particularly beneficial during this pandemic crisis, as research indicates supports are most beneficial when employees' needs are high. Finally, organizational and supervisor support interact with each other in that supervisor support is most effective when employees perceive their organization fosters a family-friendly culture (French \& Shockley, 2020).

The COVID-19 outbreak may also provide the opportunity to examine how the crisis situation may result in positive work-family outcomes. The resilience literature has shown it is possible for individuals to return to and sometimes exceed baseline levels of functioning postcrisis (Masten, 2001). Individuals may learn new strategies for managing their work and family stressors, which they can maintain after the pandemic crisis is over. Couples may have a newfound understanding of each other's work and family demands and may have learned new ways of effectively communicating with each other. If the couple is able to successfully navigate this pandemic crisis together, their marriage may come out stronger on the other end. For example, research on military families has shown that when families are able to "make meaning" of a deployment, they demonstrate improved capacity to deal with future challenges and greater family cohesion (MacDermid Wadsworth, 2010; Riggs \& Riggs, 2011). Supervisors and key organizational decision-makers may now have a more comprehensive understanding of the challenges of working parents, which can hopefully result in improved family-friendly policies. 
Finally, the increased time spent with children provide unique opportunities for greater involvement of children in family activities and foster improved emotional connections between parents and children that may improve long-term family functioning.

\section{Telecommuting}

Telecommuting (also known as telework, flexplace, and remote work) is an alternative work arrangement where workers substitute at least some portion of their typical work hours to work away from a central workplace -- often from home -- using technology to interact with others and to complete work tasks (Allen, Golden, \& Shockley, 2015; Gajendran \& Harrison, 2007). Telecommuting began gaining traction in the U.S. in the 1970 s (Avery \& Zabel, 2001) and about $16 \%$ of the workforce in the U.S. worked remotely in 2018 (BLS, 2019). If 2020 statistics were compared to previous years we would see yet another COVID-19-related exponential curve. Exact figures are difficult to estimate at this point, but it seems that telecommuting is now almost ubiquitously being used as a means of physical distancing for jobs amenable to remote work. Thus, understanding evidence-based best practices for telecommuting has never been more relevant as it is during this pandemic crisis (see also Cho, 2020; Kramer \& Kramer, 2020).

There is a substantial body of existing, interdisciplinary literature aimed at understanding the link between telecommuting and individual and organizational outcomes. The bulk of this work is cross-sectional and compares remote workers to standard arrangement workers, generally highlighting the basic association between work arrangement status and outcomes such as productivity or job satisfaction (e.g. Allen et al., 2015; Gajendran \& Harrison, 2007; Shockley, 2014). Meta-analytic findings generally suggest null or small differences between telecommuters and standard workers. Differences are typically favorable for the telecommuters, 
as they show slightly higher job satisfaction, supervisor- or objectively-rated performance, and lower turnover intentions and role stress.

Despite this knowledge, the literature still lacks a more fine-grained view of how contextual factors that vary within different remote work arrangements relate to key outcomes. Examples of contextual factors include variables such as task interdependence, frequency and nature of communication, team cohesion, supervisor behaviors, knowledge sharing, and trust perceptions. Given that so many employees are working remotely during COVID-19 under such different working conditions in a variety of industries, the time is ripe to study these issues. Doing so will allow us to offer more evidence-based best practices to telecommuters and organizational stakeholders. However, it may be difficult for researchers to design and implement studies during this (hopefully) short time span, but retrospective reports could also be quite useful, especially if drawing from objective organizational data (e.g., productivity records; communication records, etc.). Moreover, any attempts to draw conclusions about productivity at this time should certainly take into account family structure variables, given the closings of schools and daycares.

Beyond studying telecommuting arrangements during this pandemic crisis, researchers should consider the longer-term impact that a forced large remote work force will have on future organizational perceptions regarding telecommuting. One of the main barriers that employees cite to working remotely is an organizational culture that does not support it (e.g., Batt \& Valcour, 2003; Brewer, 2000). This is especially true when organizations have a high face-time versus results-oriented culture and reward people for physical presence at work (Shockley \& Allen, 2010). Speculatively, being forced into remote work arrangements may change the way executives view remote work and can serve as the needed "culture shock" to facilitate long-term 
cultural changes about remote work. Researchers should examine the impact of these cultural changes on post-COVID telecommuter effectiveness and well-being.

Moreover, the intersection of work-family issues and telecommuting has been highlighted during the pandemic crisis. One particularly salient area concerns boundary management preferences, which refer to people's preferences regarding how they manage multiple life roles. Some people like to keep roles very segmented, not thinking about one role while in the other, whereas others do better when roles blend together and are integrated throughout the day (Ashforth, Kreiner, \& Fugate, 2000). One known challenge of telecommuting is that it makes segmentation of work and family roles difficult, as both are taking place in the same location (Kossek, Lautsch, \& Eaton, 2006). For those with strong segmentation preferences, forced telecommuting is likely to create challenges in terms of increased role blurring and likewise perceptions of work-family conflict and difficulty detaching from work. As such, research focused on practical strategies to help remote workers preserve role segmentation would be quite useful. Some suggestions that exist in the literature and popular press include having a separate office with a door, coming up with an alternative "commute strategy" such as walking around the block to mentally separate the day, and getting fully ready for the day as you would if going into work. However, the extent to which these have actually been empirically tested varies, and it would be useful to have empirical information on the efficacy of these ideas. Lastly, from a practical standpoint, one of the first best practice recommendations given to new telecommuters is to make sure that telecommuting is not used as a form of childcare. Indeed, some organizations require telecommuters with children to sign a formal contract stating that they have alternative childcare arrangements. Clearly, COVID-19 has turned this idea on its head, with the closing of schools and other childcare facilities. There is no research, to our 
knowledge, on how employees can manage this situation. Although clearly pandemic crises are unusual circumstances, occasional working from home with childcare needs happens to most parents at some point due to frequent child illness. Research, perhaps starting with qualitative reports of parent's "triumph" and "tribulation" stories during this time, could pave the way for a better understanding of the best practices for short term handling of family responsibilities while working remotely in the future. Additionally, tying in with ideas in the work-life balance section, research aimed at helping employees cope with this struggle would be useful. Specifically, during this trying period many parents are not going to live up to their ideal performance in their parent and/or work roles. Strategies such as practicing self-compassion toward work and family roles on a daily basis are beginning to gain research traction (e.g., Nicklin, Seguin, \& Flaherty, 2019), and COVID-19 has made individual coping strategies even more relevant.

\section{Virtual Teamwork}

The term "virtual teamwork," a closely related concept to telecommuting, describes collaboration in (usually occupational) teams mediated by electronic tools and communication technologies (e.g., Hertel, Geister, \& Konradt, 2005; Maynard, Gilson, Jones Young, \& Vartiainen, 2017). Although initially introduced as categorical concepts, virtuality is better considered as a dimension on which teams can vary, from face-to-face (low virtuality) to fully mediated (high virtuality, e.g., procurement teams with members working from different countries and time zones using online project management tools exclusively, such as webconferencing, cloud platforms for file sharing, and documentation of work progress). Given the wide-spread use of electronic communication media today, most occupational teams are working with some degree of virtuality (e.g. Landers, 2019; Raghuram, Hill, Gibbs, \& Maruping, 2019). Nevertheless, the level of virtuality has been shown to matter for team effectiveness and related 
processes, such as leadership, trust, well-being, and social exchange (e.g., Breuer, Hüffmeier, \& Hertel, 2016; Hoch \& Kozlowski, 2014; Maynard et al., 2017). Notably, the construct of "virtuality" is complex and covers different dimensions, such as the degree of electronic mediation, synchronicity of communication, or geographic dispersion (e.g., Kirkman \& Mathieu, 2005). To understand virtuality effects, one has to consider these facets because they refer to partly different (psychological) processes in teams (see Hertel et al., 2017 for a theoretical framework).

In general, virtual teamwork provides a number of benefits, including (but not confined to) an expanded expertise when team staffing is based on competencies instead of spatial copresence, high flexibility and empowerment of team members, rapid work processes due to the use of different time zones (i.e., "work around the clock"), close connections to suppliers or customers, reduced expenses for traveling and office space, as well as support for regions with low infrastructure, integration of persons with low mobility, and reduction of commuting traffic and air pollution. At the same time, however, virtual teamwork also comes with certain risks, such as (perceived) social isolation, higher need for trust and more conflict potential, less control for team leaders, or slow feedback about team processes. Moreover, virtual teamwork is often associated with technological difficulties, causing extra time and daily hassles, higher selforganizing demands, and additional interference with private life (e.g., unplanned phone calls in the evening hours). As a consequence, virtual teamwork is not always attractive for workers, and companies have been hesitant to introduce virtual collaboration, and likewise reticent to train team leaders and members in using technology appropriately.

The COVID-19 pandemic crisis is changing this situation. Virtual teamwork is receiving increased attention because it provides excellent solutions for physical (not social) distancing at 
work, the dominant strategy in most countries to flatten the infection curve and avoid breakdowns of public health systems. Indeed, whereas virtual teamwork has been blamed for leading to feelings of isolation and a lack of "team spirit" in the past, virtual collaboration in times of the COVID-19 pandemic crisis provides multiple ways to continue collaboration in a safe environment and offers additional opportunities to stay socially connected and to maintain a high team spirit despite spatial dispersion. This is facilitated by using regular video conferences with the whole team (e.g., morning briefings, virtual coffee breaks), continuous communication between individual team members (e.g., online chats), and constant updates on work progress (e.g., as part of advanced groupware tools). Interestingly, such additional tools might lead to even better processes in virtual as compared to face-to-face teams, for instance, because team meetings are better structured, and team members receive more reliable information about the feeling states of the other members using online feedback tools (e.g., Geister, Konradt, \& Hertel, 2006).

Moreover, with the COVID-19 pandemic crisis, requests for (rapid) introduction and training of virtual teamwork has increased not only in "classic" work fields, such as research, sales, or procurement teams in larger organizations, but also in fields where computer-mediated collaboration is less established, for instance among school teachers, medical teams, mechanics, or in public administration. As a consequence, hands-on and easy-to use guidelines and support is urgently needed to manage these rapid shifts. Furthermore, being forced to switch to virtual teamwork - hopefully - also leads to some positive experiences and improved work processes (e.g., better prepared team meetings) that workers and organizations might want to maintain after the COVID-19 pandemic crisis (e.g., if only to be better prepared for a potential future pandemic 
crisis). Therefore, organizations and team leaders might want to prepare to collect lessons learned from the current changes for later implementation and maintenance.

In order to support these activities, more research is warranted to address the specific demands of virtual teamwork in a pandemic crisis. Particularly, there is a need more use(r)inspired research, considering specific demands and difficulties in the current situation, for instance, by using a critical incidents approach (see Breuer, Hüffmeier, Hibben, \& Hertel, 2019) rather than merely reacting to the technological development of new "tools." This research should particularly consider demands and needs when teams have to switch to virtual collaboration rapidly. Moreover, more differentiated approaches are needed, considering the dimensions of virtuality (synchronicity, geographical dispersion, mediated communication, etc.) separately in order to connect them with psychological processes (Hertel et al., 2017). In the context of a pandemic crisis, virtuality aspects are particularly relevant that allow physical distance, but at the same time increase feelings of social connectedness, such as synchronous communication with visual information that also transmit nonverbal cues for trust maintenance and mutual support.

In addition to advanced video-conferencing tools, virtual reality techniques might provide interesting opportunities to further increase the experience of connection, as well as perceived environmental control (e.g., Bailenson, 2018; Guegan, Nelson, \& Lubart, 2017). In general, more research is desirable on social bonding in teams and on coping with fatigue and self-motivation problems, considering the higher needs for social support, feelings of security, as well as structure and leadership in a pandemic crisis. Examples in this respect are gamification techniques (e.g., Suh, Cheung, Ahuja, \& Wagner, 2017) or stressing indispensability of the individual member for the team (e.g., Hertel, Konradt, \& Orlikowski, 2004; Hertel, Nohe, 
Wessolowski, Meltz, Pape, Fink, \& Hüffmeier, 2018). Moreover, information systems (e.g., automated documentation of task progress, simulations of different outcome opportunities) might further support virtual teams. In addition to the technical development, however, user experience and trust in such information systems are key for a successful and rapid integration (e.g., Glikson \& Woolley, 2020; Thielsch, Meeßen, \& Hertel, 2018), with concrete implication for a usercentric design. Finally, although virtual teamwork decreases infection risks in a pandemic crisis, it does increase the demands of specific resources such as the availability and support of suitable technologies, but also bandwidth and electricity demands, which might be scarce in a pandemic crisis. Therefore, we also need a better understanding of efficient usage of electronic collaboration media in a crisis situation for far-sighted planning and education programs.

While research is still needed, specific recommendations for practitioners are possible based on what is already known (e.g., O’Duinn, 2018; Maynard et al., 2017). First of all, if virtual teamwork is perceived as a desirable solution, organizations need to increase efforts to digitize their work processes, not only investing in appropriate hardware and software solutions but also adapting their work routines and providing appropriate training and ongoing support for virtual teams. Digitization of work has been a permanent and quite visible topic in Human Resource outlets for a while now, however, many (particularly small and mid-size) organizations have not yet reached the full potential, probably due to anticipated implementation costs and hassles mentioned earlier.

The current pandemic crisis, although coming with many humanitarian and economic costs, might be used as an opportunity to mobilize management as well as Human Resource departments and general staff to develop new forms of virtual teamwork, not only for the crisis situation but also beyond. Lessons learned from the current situation might be an excellent 
starting point for a general digitization strategy, such as successful leadership concepts for virtual teamwork, design of and resources for groupware solutions, or technological infrastructure. Moreover, team leaders and members need to be trained in media usage competencies in addition to technology competence, for example, how to conduct an efficient and positively experienced web-conference with larger teams, how to provide online feedback constructively, how to detect and manage conflicts in time, or how to develop and maintain trust and feelings of connectedness across physical distance. In addition, open exchange and knowledge management within but - if possible - also across companies and even businesses (e.g., what can telemedicine learn from sales or procurement teams) might be a promising avenue for innovation and learning. Virtual collaboration might help sharing (and finding) best practices for specific issues (e.g., virtual meeting rules), but can also help to develop new ideas to support (purposeful) work, which in turn can help in maintaining a healthy sense of agency and control for employees. Finally, the current crisis is also an opportunity to rethink what "really matters" in existing teams and for ongoing projects. In addition to emphasizing mutual support and maintaining high levels of team spirit, the purpose and impact of the teamwork for the organization and beyond should be stressed, reflected, and perhaps revised (McGregor \& Doshi, 2020).

In addition to such opportunities, a few risks should be mentioned as well. Although organizations ought to be open minded for new technologies to support their teams, they should not try to adopt each and every new trend. Instead, organizations are well advised to concentrate on the specific demands and needs of their teams as main criteria. Indeed, these demands can be quite different for various teams and organizations, for instance, due to different tasks, training backgrounds, or collaboration cultures. Therefore, empirical analyses of demands would be most desirable. Moreover, security and data protection issues have to be considered, particularly when 
people work from home with Internet connections that have lower security standards. Finally, environmental issues have to be considered. Whereas telecommuting and virtual teamwork help to reduce commuting and business travel costs (including air pollution), the higher electricity demands of communication media with high bandwidth (e.g., video-conferencing, team meetings with Virtual Reality applications) require reflected and responsible usage, particularly in times of rapid changes when the infrastructure (e.g., server parks) still has to be adapted. Thus, team leaders and members need also to be educated about the environmental consequences of media applications in addition to the social and health implications.

\section{Job Insecurity}

With the COVID-19 crisis expected to go on for months, many employers have turned to furloughing or laying off employees to stay afloat. A recent poll found that $33 \%$ of Americans surveyed reported that they or a family member have lost a job as a result of the pandemic crisis and $51 \%$ report that they or a family member have had work hours or pay cut (Langer, 2020). An even greater percentage of workers indicated they are concerned about potential job loss or cuts in hours or pay $(58 \%, 53 \%$, respectively), and $92 \%$ indicated that they see a recession as at least somewhat likely.

Clearly, there is a tremendous amount of job insecurity among those still employed. Job insecurity is defined as "a perceived threat to the continuity and stability of employment as it is currently experienced" (Shoss, 2017, p. 1914). Quantitative job insecurity captures the potential loss of one's job as a whole, whereas qualitative job insecurity concerns the potential loss of valued job features and a deterioration in working conditions (Hellgren et al., 1999; Vander Elst et al., 2014). The rise in job insecurity is problematic given that it has been linked to a host of 
short- and long-term negative outcomes for individuals, organizations, and communities (De Witte, 2016; Jiang \& Lavaysse, 2018; Shoss, 2017).

The COVID-19 pandemic crisis and associated economic consequences have ushered in experiences of job insecurity that are, in several key respects, fundamentally different than what has been described in past research. In particular, job insecurity (more specifically, quantitative job insecurity) has always implied a permanent separation from the organization. This has been the case through the recessions of the 1980s and the Great Recession, as well as the widespread corporate downsizings and restructurings of the 1990s. However, given the unique nature of the current crisis, employees may expect/hope to return to work for their employer after the crisis. Thus, job insecurity, in many cases, may not reflect an anticipation of a permanent separation from the organization. Rather, it may reflect insecurity about a short(er)-term separation. This is a critical shift from the experiences of job insecurity examined in past research, and therefore, it raises questions about the applicability of past findings in the current context. Moreover, it suggests that research on job insecurity needs to be expanded to incorporate and compare different types of job insecurity experiences, and to examine how events surrounding insecurity (e.g., organizational communication) shape employees' willingness to return to the employer and their behaviors/attitudes/cognitions upon return.

The crisis has also led to inherently different experiences of qualitative job insecurity. Medical professionals and first responders are experiencing considerable uncertainty about the future intensification of their work experiences and the sacrifices that will be required of them and their families as this crisis unfolds. Researchers would do well to examine these cases of qualitative job insecurity (perhaps an appropriate term would be intensification qualitative insecurity), to compare intensification qualitative job insecurity to more deprivation-focused 
experiences of qualitative job insecurity, and to examine the impact of intensification qualitative job insecurity on individuals, families, and workplaces in the short- and long-terms.

At the same time as these changes in the meaning and experience of job insecurity suggest new research that needs to be conducted, they also suggest several new directions and recommendations for practice (which should also be researched). First, people may view longterm quantitative job security as an (not ideal, but) acceptable substitute for short-term quantitative or deprivation-based qualitative job insecurity. For example, in anecdotal discussions with employees in a health care company that reduced work hours and pay due to the crisis, employees indicated that they would be willing to accept some uncertainty surrounding their job conditions as long as they know that they will have a job to which to return. Organizations may benefit from bolstering perceptions of long-term job security, even if they are unable to address short-term concerns.

Second, it is important that organizations operate with transparent and frequent communication and handle layoff/furlough situations with justice and sincerity. These conditions have been linked to lowered job insecurity and more positive responses from layoff victims and survivors (Jiang \& Lavaysse, 2018; Richter et al., 2016; Skarlicki et al., 2008). Managing these situations with a goal of reducing uncertainty and supporting well-being may help ensure that employees return and do so with positive views of the organization. This crisis, while gravely unfortunate, may represent an opportunity for organizations to demonstrate support for their employees that may pay dividends when this crisis passes.

Third, it may be beneficial for organizations to provide employees with a means by which to feel that they will remain part of the organization's social fabric regardless of temporary furlough/layoff status (e.g., an employee Facebook group to share resources and 
support, shared opportunities for training). One of the reasons that job insecurity is thought to be so impactful is because it frustrates basic psychological needs (Vander Elst et al., 2012). Jobs provide identity, esteem, social connection, meaning, skill development, and so forth (Hulin, 2002). To the extent to which employers can enable employees to maintain these psychologically-enriching experiences regardless of temporary job loss, they may help employees to cope with potential or actual loss and enable a more positive transition back to work.

Finally, if it all possible, organizations and governments should help employees manage economic uncertainty. Research suggests that economic uncertainty exacerbates negative reactions to job insecurity (Shoss, 2017). Many employers (e.g., Darden restaurants, Starbucks) have adopted or expanded paid sick leave policies (Jiang, 2020). Not only could this help mitigate workers' angst that they either go to work sick or lose their jobs or income, but it could also help mitigate virus spread (Bhattarai \& Whoriskey, 2020; Stockton et al., 2020). Several employers have chosen to continue to pay employees despite closures (e.g., Apple; Disney) and others have continued to pay furloughed/laid-off employees' health insurance in order to help employees manage the transition and reduce stress during this turbulent time. For those dealing with uncertainty related to intensification, organizational efforts to protect workers, support their families, and accommodate special needs may help assuage some of the negative impacts of this uncertainty. As billionaire Mark Cuban was recently credited with saying (Stankiewicz 2020), "how companies treat workers during [this] pandemic could define their brand 'for decades'."

\section{Precarious Work}

The COVID-19 crisis presents an opportunity to examine the quality and structure of work in the current labor market, particularly its implications for precarious work (see also 
Kantamneni, 2020). Precarious work broadly refers to work that is risky, uncertain, and unpredictable for workers (Kalleberg, 2009). Scholars have operationalized precarious work in different ways, mostly describing how the structure and quality of work is transforming in the modern labor market. For example, nonstandard, atypical, contingent, and alternative work arrangements all describe jobs that differ from full-time, permanent employment. Building off this work, scholars have defined precarious work more specifically as work that is unstable or short-term, lacks collective bargaining rights, provides low or unreliable wages, has few rights and protections, and does not grant workers power to exercise rights and freedoms (e.g., Benach et al., 2014). In this way, precarious work combines uncertainty in the amount and continuity of work with limited autonomy and access to power.

Across the globe, multiple forces are converging to make precarious work more prevalent (ILO, 2020). For example, since the 1980s, globalization and other factors have led to intense global competition and a subsequent reorganization of corporations to employ a smaller number of full-time, permanent workers and a greater number of part-time, temporary workers (Hall, 2004; Katz \& Krueger, 2019). In the United States, the percentage of workers in alternative work arrangements has increased 50\% from 2000 to 2015, totaling $15 \%$ of the workforce (Katz \& Krueger, 2019); these estimates are higher in other North American countries (i.e., Canada), in countries across Europe, and in Japan (see Cappelli \& Keller 2013). Estimates that include people in involuntary part-time work suggest that $20 \%$ of U.S. workers have alternative work arrangements (BLS, 2018), and millions of Americans earn poverty wages (Smith, 2015). Moreover, precarious work is inequitably distributed, with marginalized populations being more likely to hold underpaid, insecure, and temporary positions (e.g., Kalleberg \& Vallas, 2017). This presents a significant concern for IO psychologists given precarious work's negative relation to 
poorer job attitudes and mental health and its positive relation to withdrawal intentions and turnover (e.g., Han et al., 2017).

The COVID-19 pandemic crisis has exposed this precarity in the workforce and exacerbated existing issues with the contemporary structure of work. People in precarious work are particularly vulnerable to economic disruption and are less able to cope with unemployment and loss of working hours. For example, workers in precarious jobs, such as gig workers, temporary staffing agency workers, and hourly workers, are more likely to lose their jobs during the COVID-19 economic crises (Blustein et al., 2020; JQI, 2020). While many salaried workers are able to telecommute and continue their jobs, low-wage hourly workers and other precarious workers are not able to continue working during physical distancing and subsequently lose their employment. Decades of psychological research has established that unemployment has far reaching and deleterious results for individuals, including increasing depression and suicidality (Paul \& Moser, 2009). Moreover, the massive increase in unemployment after a short time of economic disruption highlights the underlying precarity of many workers' job conditions, which existed before the current economic instability (Kalleberg, 2009). It also exposes inequity within the labor market whereby people with relative power and access to resources are more able to withstand crises.

Relatedly, many people with precarious work do not have access to governmental and organizational benefits, such as employment and health insurance. These benefits help people recover from crises as they struggle with finances and health problems. For example, precarious workers are at risk for chronic stress and dangerous working conditions, leading to higher rates of mental and physical health issues, such as cardiovascular disease (Benach et al., 2014; Schnall et al., 2016). These chronic health conditions in turn may increase vulnerability to COVID-19, as 
well as mental health concerns resulting from losses of resources and economic uncertainty (Zhou et al., 2020). In essence, the workers who are most vulnerable to the current crisis are those who are less able to cope with job loss and illness.

The COVID-19 crisis is an important opportunity to (re)focus IO psychology's efforts on addressing precarious work. The issue of precarious work is not new, but the current economic crisis highlights that large proportions of Americans are working in jobs that do not provide basic security or a living wage. Diverse fields including economics, sociology, and public health have studied precarious work and advanced theories in this area, but psychology has contributed less research to these efforts. However, psychologists have developed a literature base on aspects of precarious work, such as job insecurity and temporary workers, which can serve as a base for examining what the COVID-19 crisis reveals about the labor market and how psychologists can help. For example, the COVID-19 crisis raises important questions about who is vulnerable to economic crises, what factors exacerbate financial and mental distress, and what helps people cope with economic uncertainty and turmoil. For example, research suggests that precarious workers are particularly vulnerable to health and economic consequences of the COVID-19 pandemic crisis (Benach et al., 2014; Schnall et al., 2016), and research is critically needed to understand the mechanisms involved and how to intervene effectively.

As people, organizations, and governments seek to endure and rebuild after the crisis, psychologists can play an important role in advocating for precarious workers and providing data that can inform interventions and relief efforts. Policies in the United States largely reflect the labor market of the $20^{\text {th }}$ century, and employment insurance benefits are a key example. More than ever, Americans are working in alternative work arrangements and in the platform economy (Katz \& Krueger, 2019), which cuts them off from traditional employment insurance and other 
benefits. While the CARES act stimulus extends benefits to freelancers and independent contractors, this is a short-term solution to a long-term trend of people working outside the $20^{\text {th }}$ century model of employment (Hall, 2004). As recovery occurs, psychologists can play a key role in advocating for governmental and organizational policies that reduce precarious work and increase social protections. These may include advocating for a living wage, increasing food and wage assistance, expanding Medicaid, eliminating work requirements, expanding unemployment benefits, improving the accessibility of job skills training, expanding the earned income and child tax credits, or prohibiting unemployment discrimination. Psychology has a wealth of data that can inform such policies (e.g., Smith, 2015) and improve the lives of precarious workers during and after the COVID-19 crisis.

\section{Leadership}

According to Microsoft founder Bill Gates, "In any crisis, leaders have two equally important responsibilities: solve the immediate problem and keep it from happening again" (Gates, 2020, p. 1677). Government attempts to simultaneously minimize deaths and economic decline due to the COVID-19 pandemic, as well as to mentally prepare people for the long and challenging aftermath of the current crisis and future pandemics, have led to increased feelings of uncertainty and psychological distress among many employees (Anderson, Heesterbeek, Klinkenberg, \& Hollingsworth, 2020; Sibley et al., 2020). When perceived uncertainty is high, employees are more likely to turn toward their supervisors and leaders for guidance and support, and leader behavior has stronger effects on important employee and organizational outcomes (Waldman, Ramirez, House, \& Puranam, 2001). For instance, research conducted during a merger with high uncertainty has shown that follower-focused leader behavior is positively associated with follower organizational identification, psychological empowerment, and 
engagement (De Sousa \& van Dierendonck, 2014). Thus, the pandemic crisis may offer several opportunities for advancing leadership theory and research and for implementing evidence-based leadership practices.

Leadership broadly refers to the processes by which a person (i.e., the leader) influences others (i.e., followers) to achieve common goals (Yukl, 2006). In future leadership research, the COVID-19 pandemic crisis could be addressed by examining (a) how this context influences leadership, (b) who emerges as a leader in this context, and (c) what makes leaders effective in this context. First, scholars could examine whether the COVID-19 pandemic crisis, as a context factor, leads to changes in leadership behavior in teams, organizations, industries, and countries over time. Such research could attempt to constructively replicate a recent study based on the threat-rigidity hypothesis, which showed that the 2008 financial crisis led to an increase in directive leadership, particularly in the manufacturing sector and in countries with high power distance (Stoker, Garretsen, \& Soudis, 2019). It would be interesting to compare and explain the engagement in, and preference for, different leadership behaviors before and after COVID-19.

Second, scholars could further investigate who emerges, why, and when as a leader during this organizational, economic, and political crisis (James, Wooten, \& Dushek, 2011). Research could focus on the role of individual differences for leadership emergence during the pandemic crisis. For instance, theorizing on the "glass cliff," which suggests that women are more likely to be appointed to leadership positions in crises than men because they signal "change" (Ryan et al., 2016), could be tested in the context of COVID-19. Similarly, studies could investigate whether older, more experienced leaders (Spisak, 2012) and leaders using more promotion-oriented communication (Stam, van Knippenberg, Wisse, \& Nederveen Pieterse, 2018) are not only preferred during war and organizational crises, but also during the current 
pandemic crisis. In addition, research could focus on the dynamic, interactive, and multilevel nature of leadership emergence during the pandemic crisis, including followers' individual, relational, and collective cognitive and perceptual processes regarding leadership (Acton, Foti, Lord, \& Gladfelter, 2019). Observational studies on leadership emergence during the pandemic crisis could further examine what individuals who emerge as leaders during the crisis actually "do" (and why and when they do it), including behaviors such as listening as well as task-, relationship-, and change-oriented communication (Gerpott, Lehmann-Willenbrock, Voelpel, \& Van Vugt, 2019).

Third, scholars could examine the individual and contextual factors and processes that predict leadership effectiveness during the COVID-19 pandemic crisis. Previous research in this area has identified various "leadership competencies" required in distinct crisis phases that could also be examined in the current crisis. For instance, leaders have been advised to engage in sense-making and perspective taking in the "signal detection phase," in issue selling and creativity in the "prevention and preparation phase," and in decision making, communication, and risk taking during the "damage control and containment phase," before entering the "recovery phase" and the "learning and reflection phase" (Wooten \& James, 2008). Building on this research, it would be important to theorize on and examine specific leader behaviors that address the unique demands of the current pandemic crisis. Such research would have to start with a systematic analysis of the various new task, relational, and cognitive demands faced by leaders in this crisis. For instance, the COVID-19 pandemic crisis urgently calls for examining research questions on the notion of "digital leadership" (sometimes also called e-leadership or virtual leadership), as many leaders and their followers are now forced to work remotely from home (Larson \& DeChurch, 2020; see also the sections on virtual teams and telecommuting). In 
this context, follower perceptions of leader communication, trust, justice, and granted autonomy seem particularly relevant.

The COVID-19 pandemic crisis may also require leaders to manage a paradox between employee health and well-being on the one hand and maintaining or restoring profitability on the other. Thus, researchers could test whether "paradoxical leadership" is particularly effective in the current crisis (Zhang, Waldman, Han, \& Li, 2015). In addition, social psychologists have recently offered "identity leadership" as a new and potentially effective form of leadership in the COVID-19 pandemic crisis, which involves leaders representing and promoting the shared interests of their followers as well as creating a sense of collective social identity among them (Haslam, Reicher, \& Platow, 2011; Van Bavel et al., 2020). Finally, research on the notion of “healthy leadership" could explore associations among leaders' and followers' health-related attitudes, values, behaviors, and outcomes during a stressful and uncertain time that places various novel demands and constraints upon them, both within and outside of the work context (e.g., job insecurity, work-family conflict; Rudolph, Murphy, \& Zacher, 2019).

Importantly, scholars who study leadership with a particular focus on the COVID-19 pandemic crisis should theoretically justify why a leadership construct or process is assumed to have different (or the same) effects during a specific time period or a country/region that is strongly influenced by the pandemic crisis, as compared to other (previous or future) time periods or countries/regions. Moreover, when introducing any new leadership construct, it is important to demonstrate incremental effects above-and-beyond those of already established leadership constructs, such as task-, relational-, and change-oriented forms of leader behavior (DeRue, Nahrgang, Wellman, \& Humphrey, 2011). We particularly caution against the introduction of a novel "COVID-19 pandemic crisis leadership behavior" construct, as it is likely 
to have a great deal of conceptual and empirical overlap with existing, well-established leadership constructs (e.g., initiating structure, consideration, charismatic leadership style; Stam et al., 2018). Thus, it would not explain a significant amount of additional variance in important follower and work outcomes (see also Rudolph et al., 2019).

In addition to research opportunities, it is important to discuss evidence-based practical implications for leadership in the COVID-19 pandemic crisis. First, organizations should select leaders who possess the relevant knowledge, skills, and personality characteristics to successfully navigate the unique demands of a crisis, such as the current pandemic (e.g., recognition of and dealing with specific threats and opportunities for employees and the organization; Wooten \& James, 2008). Second, as many leaders do not received formal training to manage crises, it is important to integrate crisis management knowledge and skills into future leadership development programs and learn from errors made during earlier crises (Day \& Dragoni, 2015).

Third, leaders should be encouraged to take care of both their own and their followers' health, while maintaining high performance. For instance, research suggests that high levels of leader presenteeism (i.e., working despite being ill) can spill over and increase employee presenteeism which, subsequently, leads to higher employee sick leave (Dietz, Zacher, Scheel, Otto, \& Rigotti, 2020). Finally, due to several problematic issues with the notion of "generations" and "generational differences" (Rudolph, Rauvola, \& Zacher, 2018), it is advisable that leaders do not attempt to manage an assumed "COVID-19 generation" (see Rudolph \& Zacher, 2020), but rather adopt an individual-focused lifespan perspective on their followers' development, performance, and well-being (see also the section on the aging workforce).

\section{Human Resources Policy}


The evolving COVID-19 pandemic crisis has put pressure and demands on Human Resource (HR) departments and managers to quickly adjust their policies and practices. HR responsibilities in organizations consist of both traditional or operational and strategic tasks (Wright \& Ulrich, 2017). The current crisis requires actions on the operational side of HR practices, but at the same time also has potential for strategic HR initiatives that might help organizations get "back to business" as soon as possible after the crisis.

On the operational side of HR management, health and hygiene measures for all employees are the top priority for most employers right now. As COVID-19 is a virus that spreads between human beings, physical distancing is key to lower infection rates between employees and keep operations running. Measures to achieve physical distancing differ between white-collar or office employees and blue-collar or production employees. White-collar employees can relatively easily move to home office settings and communicate virtually to complete their work tasks. HR departments, in cooperation with information technology (IT) divisions, have to ensure that employees have the right IT equipment and competencies to work remotely. Short video or blended-learning opportunities, for example, explaining how to host video conferences and keep up team-based collaborations in virtual settings, might be particularly helpful for employees who have limited experience with working remotely (see also the sections on telecommuting and virtual teamwork).

Furthermore, many employees are confronted with childcare obligations due to closed schools and kindergartens. As a consequence, HR departments have to tailor idiosyncratic deals (I-deals) for these employees, including negotiating specific time and work arrangements that fit their current situation (Rousseau, Ho, \& Greenberg, 2006). For flexible and telecommuting arrangements, I-deals have been shown to lower work-family conflict and increase the work 
engagement of telecommuting employees (Hornung, Rousseau, Glaser, 2008), as well to improve contextual work performance (Gajendran, Harrison, Delaney-Klinger, 2015). As a consequence, HR departments should allow as much leeway as possible in terms of work and time arrangements for white-collar employees in the current situation (see also Spurk \& Straub, 2020).

For blue-collar workers, especially those in critical industries that cannot fully shutdown their capacities, reducing the social density of shifts by moving away from standard eight-hour shifts for everybody to more flexible arrangements, as well as the separation of employee shifts, is essential for lowering infection rates. Beyond these immediate measures, organizations, supported by HR departments, need to develop better hygiene cultures that enable a healthy workforce, if the COVID-19 situation lasts over months or worst case, even years. Here companies might benefit from public health research that has a track record of successful interventions for hygiene procedures (i.e., hand washing) in hospitals. One concrete application of this are positive deviance (PD) change procedures that have, for example, helped to reduce hospital-wide infection rates by more than 50\% (Lindberg et al. 2009). Concrete practical applications of such procedures, as defined by Sternin (2003), include setting measurable goals for the change initiative (e.g., increasing hygienic/physical distancing behaviors of employees), determining certain groups of employees that already show such behaviors and thus positively deviate from the norm, and designing processes within the organization such that these positively deviating practices can be implemented throughout the organization. In particular, for the last step of this process, HR policies should be adjusted such that they provide communication and leadership training efforts to support such initiatives. Designing intervention studies to address 
how such hygiene-focused HR practices can be successfully implemented should be the top priority for the HR research community.

Beyond immediate operational measures, the COVID-19 crisis also calls for action from a strategic HR perspective, defined as the required human resource behaviors that enable the organization to achieve its goals through maintaining the right human capital resources (Wright \& McMahan, 1992). The current situation entails the risk that companies will experience a massive loss of talent due to the immediate breakdown of the economy that results in drastically rising unemployment as currently seen in the United States and beyond (e.g., Europe and Asia, as mentioned previously). Even though many companies are forced to downsize right now, there might be a way to execute this reactive downsizing in a commitment-oriented way (Zatzick, Marks, Iverson, 2009). Following this approach, companies should target downsizing towards underperforming units while retaining talent in well-performing areas, and at best, avoid involuntary layoffs. Measures such as temporary shutdowns, state-subsidized short-worker allowances (i.e., as mentioned previously, and available in many European countries, like Germany), should be used to soften downsizing procedures. Furthermore, HR managers should strive for a transparent and fair way of communication about downsizing measures. This is crucial, as research shows that downsizing procedures can increase later voluntary turnover of remaining employees (Trevor \& Nyberg, 2008), and the resulting costs can be up to $\$ 100,000.00$ for top executives (Brockner, 2006).

Additionally, companies can also use temporary production lockdowns or increased telecommuting arrangements to strategically grow the skill sets of their workforce via online education programs. In this case, if the company has enough slack resources to at least temporarily retain most of their personnel, intermediate production and service shutdowns might 
be used to digitally built skills and competencies that are helpful during the crisis (e.g., health and safety relevant trainings) and after the disaster (e.g., digital communication and sales skills in future markets, with fewer travel-activities and in-person sales). As for remote working and virtual teamwork, the current crisis and resulting lockdowns have the potential to also disruptively transform the education market towards e-learning and online education that has yet to be widely used by technological and IT-focused companies (Batalla-Busquets \& MartínezArgüelles, 2014). Thus, strategically investing in online training and development environments is one of the HR-related opportunities originating from the current crisis, and empirical HR research will have to test if it indeed pays off in increasing employee skills and productivity in the mid- and long-run.

\section{The Aging Workforce}

The global aging of the workforce is now a well-defined phenomenon; the average age of workforces across the globe, in both industrialized and emerging economies, is increasing. This has resulted in an older and more age-diverse workforce than we have ever seen before (See Rudolph, Marcus, \& Zacher, 2018). For example, population projection estimates suggest that over $30 \%$ of the populations of the majority of developed economies will be aged $65+$ by 2050 (UNDESA, 2015). Such trends can be explained, in part, by declining birth rates coupled with medical advances leading to extended healthy lifespans. Economically speaking, maintaining employment past traditional retirement ages will be all but required to maintain pension systems. Accordingly, the aging workforce presents both challenges (e.g., maintaining productive work performance beyond traditional retirement age; supporting a multigenerational workforce) and a number of opportunities (e.g., harnessing accrued job knowledge) for individuals, organizations, and economies (Hertel \& Zacher, 2018). The global scope of the COVID-19 pandemic crisis 
combined with the aging of the workforce and higher morbidity rates among those aged 60+ (e.g., $>80 \%$ of deaths have occurred among persons aged $\geq 60$ years of age; CDC 2020) presents a particularly unique combination of factors, with implications for both research and practice in IO psychology.

Although there are many theoretical frameworks that could be adopted to conceptualize the impact of COVID-19 on the aging workforce, researchers would be wise to adopt a lifespan developmental perspective (see Baltes, Reese, \& Lipsitt, 1980; Rudolph, 2016). The lifespan developmental perspective is a meta-theoretical framework that views developmental outcomes as a product of three co-occurring influences, including normative age-graded influences (e.g., age-graded changes in cognitive function or emotion regulation capacities), normative historygraded influences (e.g., economic conditions; pandemic crises), and non-normative/idiosyncratic influences (e.g., health issues, unemployment). In order to translate these developmental influences into testable research questions concerning the impact of COVID-19 for the aging workforce, researchers could consider both differential susceptibility (Belsky \& Pluess, 2009) and differential impact theoretical frameworks (e.g., Ungar, 2017) as compliments to the lifespan perspective.

On the one hand, differential susceptibility suggests that certain individual differences (e.g., age; personality) make individuals more-or-less susceptible to features of their environments. Differential susceptibility thus focuses attention on individual characteristics that help explain why some people are more or less vulnerable to environmental influences, and in particular, changes in environmental factors. Thus, differential susceptibility proposes a personby-situation interaction, where chronological age could be construed as a person characteristic. In adopting a differential susceptibility argument, researchers might ask questions about whether 
the consequences of COVID-19 manifest differently for workers of different ages. Researchers could ask questions about the impact of COVID-19 on any number of topics considered here (e.g., job insecurity) and whether workers of different ages are differentially susceptible to such impacts. For instance, in considering how workers of various ages differentially react to their environments, researchers could ask questions like 'Is age a 'risk factor' for predicting job insecurity or unemployment during or following the pandemic crisis?"

On the other hand, differential impact considers how environmental changes serve as risk factors that "shape" or change individuals, and in particular how various resources (e.g., psychological, sociocultural, and economic) serve to mitigate or enhance individuals' exposure to such environmental risks. Thus, differential impact considers resource-by-environment interactions that either directly, indirectly, or conditionally affect workers of different ages (i.e., especially one age "group" versus another: e.g., "younger," “middle-age," or "older workers"). In adopting a differential impact argument, researchers might ask questions about whether workers of different ages are more-or-less at risk of the consequences of COVID-19 (i.e., in particular to consequent environmental changes, like the implementation of mass work-fromhome policies), and whether various resources may offset or mitigate such risk (e.g., psychological resources, like technology literacy; sociocultural resources, like family support). For example, researchers could ask questions about how environments differentially support workers of different ages, such as "How are working from home and related HR-policies for managing work processes during the pandemic crisis differentially impacting workers of different ages?" Importantly, both differential impact and susceptibility hypotheses could likewise be pitted against one-another in a strong inference framework (Platt, 1964). In doing so, researchers should consider age as a moderator (e.g., to index differential reactivity), in addition 
to various age-related mediators (e.g., age affecting work outcomes via environmental reactions, to index differential reactivity; see Bohlmann, Rudolph, \& Zacher, 2018).

While informative of research, the lifespan perspective and various research questions that can be posed from the differential reactivity and differential impact frameworks have bearing on practice as well. For example, evidence for differential reactivity or differential impact could variously help with the development of "age management" strategies that are informed by lessons learned from this pandemic crisis. Generally speaking, the term "age management” refers to “...various dimensions by which human resources are managed within organisations with an explicit focus on ageing and, also, more generally, to the overall management of workforce ageing via public policy or collective bargaining" (Walker, 2005, p. $685)$.

At the same time, practitioners should exercise caution against the idea of hastily customizing work policies to people of different ages, especially if such customizations are not backed by good empirical evidence. For example, already there have been suggestions in the media that work from home policies are especially beneficial for younger workers (Roose, 2020; Withane, 2020), yet this remains an open and untested question. Moreover, although practitioners are encouraged to consider applications of "age management" that are informed by evidence, they should be cautioned to avoid various pitfalls of "generations management." Importantly, the lifespan framework eschews the notion of generational differences (see also Rudolph \& Zacher, 2017; 2020). Given the wide-sweeping global impact of COVID-19, it makes the most practical sense to consider the impacts of this pandemic crisis for workers of different ages, rather than to make assumptions about "generation" membership (Rudolph \& Zacher, 2020a, 2020b; see also Ayalon, 2020; Ayalon et al., 2020). 
Following the advice above, practitioners are especially encouraged understanding how people of different ages are differentially impacted by, and/or react differently to, environmental changes resulting from this pandemic crisis. To support an aging workforce, practitioners would be well served to think about developing interventions to mitigate such impact or reactivity effects. For example, one area of practice regarding older workers that is very likely to be impacted by the COVD-19 pandemic crisis concerns retirement plans and patterns. It is likely that there will be disruptions in such plans and patterns stemming from drops in market value. Specifically, older workers' retirement plans are likely to be differentially impacted relative to younger workers in this way. Applying this advice, organizations could intervene in various ways to mitigate this impact. For example, organizations could consider various strategies for helping older workers navigate these precarious financial decisions. The development of phased retirement schemes and return to work programs (e.g., deliberately re-recruiting retirees as “bridge employees;” see Shultz, 2003) would be particularly helpful in this regard.

\section{Careers}

A career describes the sequence of a person's work experiences over their life course (Hall, 2002). An examination of how the COVID-19 pandemic crisis affects careers thus needs to focus on how it might affect people's work in the mid- to long-term (see also Akkermans, Richardson, \& Kraimer, 2020). One of the most salient consequences for a significant number of employees, is that their employing business has (perhaps only permanently) shut down due to government restrictions or lack of consumer demand. As suggested above, this has already resulted in record numbers of people becoming unemployed within a very short period of time (Casselman et al., 2020). In a best-case scenario, when the virus is quickly controlled, this unemployment might be temporary, and workers could go back to their employers and the same 
jobs after a short period of time (see also the section on job insecurity). However, especially if the influence of the pandemic crisis persists, many affected companies will go out of business permanently, potentially causing longer periods of unemployment for their former employees even after the pandemic crisis is controlled.

Research shows that especially longer and repeated spurs of unemployment can significantly affect career development and disturb career progression (e.g., Gregg \& Tominey, 2005; Schmillen \& Umkehrer, 2017). This adverse effect can occur because unemployment diminishes critical career resources in terms of human capital (e.g., professional skills and knowledge), social capital (e.g., networks, social support), and psychological resources (e.g., hope, self-efficacy), which are critical for objective and subjective career success (Hirschi, 2012; Spurk et al., 2019). In addition, unemployment might lead to career changes that alter career trajectories, irrespective of career advancement.

Indeed for many employees, the pandemic crisis will likely act as a career shock -- an unexpected, distinct, and impactful event that triggers a deliberation about potential career transitions (Akkermans et al., 2018; Akkermans et al., 2020; Seibert et al., 2013). Hence, apart from more immediate effects on career development due to unemployment, the pandemic crisis could also have more intermediate effects on career attitudes. Even for employees not affected by unemployment, the current situation can create a significant amount of job insecurity (Cox, 2020a,b; see also section on job insecurity). Besides its imminent negative effects on well-being and performance (Lee Huang, \& Ashford, 2018), job insecurity might lead to an active career engagement, whereby employees start to explore career alternatives, activate their professional and private networks, or consider re-training in an attempt to increase their marketability (Spurk et al., 2015). However, experienced job insecurity might also lead to less career risk taking, 
because security needs might become more salient. The crisis could also affect adolescents and students in their career choices. Specifically, the consequences of the pandemic crisis could negatively affect outcome expectations (Lent \& Brown, 2019) regarding some careers (e.g., service industry, tourism), in that such careers become less attractive due to their risk of being significantly negatively affected by potential future pandemic crises. Conversely, careers in sectors that gain in importance due to the crisis (e.g., health care, digital companies) might increase in attractiveness.

Despite the potentially profound negative effects on many people's career development, the crisis might also have some positive impacts. In some instances, unemployment can lead do a re-consideration of one's career choices, an exploration of new career opportunities, and a voluntary change of occupations and sectors, resulting in improved job quality (Zikic \& Klehe, 2006). In addition, the crisis could lead people to a more sustainable approach to career selfmanagement. Specifically, many might realize that personal health, social connections to family and friends, and community involvement have been undervalued. This could lead to a more wholistic, whole-life approach to career development and career choice, where work and nonwork goals are equally and simultaneously considered in career self-management, resulting in more satisfying and sustainable careers (Hirschi et al., 2020). In addition, numerous students and employees are volunteering in health care and community services during the crisis (Ali, 2020). Such volunteering might expose them to new career learning, for example, by discovering new interests and strengths, building new human, social, and psychological career resources, and exposing them to new career opportunities that might prove beneficial for their future careers. An important avenue for research is to examine if and how the crisis affects career experiences and trajectories. As outlined above, career effects might stem from becoming unemployed, job 
changes, or volunteering experiences. In addition, researchers should investigate how the crisis changes psychological career resources, career attitudes, and behaviors, including career aspirations and career choices, and how such changes affect career development in both positive and negative ways.

For practice, public policy should focus on controlling the spread of the virus through public health measures and helping people remain employed by financially supporting businesses that are most affected. This could prevent negative career effects of unemployment. In addition, for employees and the unemployed, volunteering can be promoted and coordinated as a way to maintain or gain new career resources. Psychologists working in HR, job placement, or career counseling could assist employees experiencing career insecurity and the unemployed with evaluating the implications for their careers, including if and how they might want to consider alternative career paths and occupations -- temporarily or permanently. In addition, exploring options for volunteering might be a good way to expand career prospects and work meaningfulness during the crisis. Career counselors working with students should take into account that the current crisis might have affected their career outlook and aspirations. The ways in which this occurred and its implications for career preparation, planning, and career choice should be explored in career counseling sessions. Finally, career counselors might want to take the crisis as an opportunity to help clients re-assess their priorities in work and life and help clients identify and pursue career goals under consideration of work and nonwork roles and priorities.

\section{Conclusions}

From the preceding 10 sections, COVID-19 will clearly have wide-sweeping effects on processes that broadly affect the nature of work and organizations, and, more importantly, 
directly affect employees. We have focused purposefully on the influences of the pandemic crisis on occupational health and safety, work-family issues, telecommuting, virtual teamwork, job insecurity, precarious work, leadership, human resources policy, the aging workforce, and careers. These topics represent, in our view, those most likely to be "disrupted" by the COVID19 pandemic crisis. However, clearly, there are additional topics in IO psychology that may be relevant to the current pandemic crisis that were not covered explicitly or directly here (e.g., personnel recruitment, selection, and training; work analysis and work design; performance management; justice within organizations; employment relations and psychological contracts; adaptive and proactive behaviors, such as employee silence and voice; organizational culture and cross-cultural differences; see also Fouad, 2020; Gibson, 2020). Thus, we especially call on our colleagues to consider how additional topics in our field will be affected by COVID-19.

Our goal with this article was to raise important questions to stimulate new research and practice discussions regarding these topics (see Table 2), rather than presenting the evidence reviewed here as the "final word" on these issues. To support this, we call on researchers to undertake systematic efforts at evidence synthesis (i.e., systematic reviews and meta-analyses, especially of intervention studies) in these 10 areas, and beyond, and for practitioners to apply evidence from such syntheses as the basis for (re)developing organizational policies and practices in preparation for future pandemic crises (e.g., Carlsson, 2020).

Clearly, the impact of COVID-19 will present a broad variety of challenges and opportunities for research and practice in IO psychology. Indeed, as Steven Taylor (2019) wrote in The Psychology of Pandemics, even though a pandemic crisis can cause an increase in xenophobia, panic reactions, and superstition, humans show also an increase in solidarity and mutual support. We hope that our field can help to curtail the former, and encourage the latter, 
and we invite our colleagues to "make this happen." In light of this pandemic, the field of psychology, broadly defined, has been criticized for not being "crisis ready" (IJzerman et al., 2020). IO psychology is in a unique position to help shape the future of work and help encourage the types of organizational policies and practices that will ensure readiness for potential future pandemic crises. Thus, we hope that this focal article serves as a "grand challenge" to IO psychology researchers and practitioners to face the challenges and opportunities of COVID-19 and future pandemics head-on by proactively innovating the work we do in support of workers, organizations, and society as a whole. 


\section{References}

Abedin, A. (2020, April 20). Finding jobs and building careers in the age of COVID-19 and beyond. Entrepreneur. Retrieved from: https://www.entrepreneur.com/article/349473

Acton, B. P., Foti, R. J., Lord, R. G., \& Gladfelter, J. A. (2019). Putting emergence back in leadership emergence: A dynamic, multilevel, process-oriented framework. The Leadership Quarterly, 30(1), 145-164. doi:10.1016/j.leaqua.2018.07.002

Adams, J. G., \& Walls, R. M. (2020). Supporting the health care workforce during the COVID19 global epidemic. Jama, 323(15), 1439-1440. doi:10.1001/jama.2020.3972

Adams, K. (2020, May 4). COVID-19 has some older workers rethinking retirement. Marketplace. Retrieved from: https://www.marketplace.org/2020/05/04/covid-19-hassome-older-workers-rethinking-retirement/

Adler, A. B., Adrian, A. L., Hemphill, M., Scaro, N. H., Sipos, M. L., \& Thomas, J. L. (2017). Professional stress and burnout in US military medical personnel deployed to Afghanistan. Military Medicine, 182, e1669-e1676. doi:10.7205/MILMED-D-16-00154

Adler, A. B., Bliese, P. D., McGurk, D., Hoge, C. W., \& Castro, C. A. (2011). Battlemind debriefing and battlemind training as early interventions with soldiers returning from iraq: Randomization by platoon. Journal of Consulting and Clinical Psychology, 77, 928-940. doi: $10.1037 / \mathrm{a} 0016877$

Agars, M. D., \& French, K. A. (2016). Considering underrepresented populations in work-family research. In T. Allen and L. Eby (Eds.), The Oxford Handbook of Work and Family (pp. 362-375). New York: Oxford Press. 
Akkermans, J., Richardson, J., \& Kraimer, M. (2020). The Covid-19 crisis as a career shock: Implications for careers and vocational behavior. Journal of Vocational Behavior. doi:10.1016/j.jvb.2020.103434

Akkermans, J., Seibert, S. E., \& Mol, S. T. (2018). Tales of the unexpected: Integrating career shocks in the contemporary careers literature. SA Journal of Industrial Psychology, 44(1), 1-10. doi: 10.4102/sajip.v44i0.1503

Ali, S. S. (2020, March 27). As parents fight on COVID-19 front lines, volunteers step in to take care of their families. NBC News. Retrieved from: https://www.nbcnews.com /news/us-news/parents-fight-covid-19-frontlines-volunteers-step-take-care-their-n1169931

Allen, T. D., Golden, T. D., \& Shockley, K. M. (2015). How effective is telecommuting? Assessing the status of our scientific findings. Psychological Science in the Public Interest, 16, 40-68. doi:10.1177/1529100615593273

Anderson, R. M., Heesterbeek, H., Klinkenberg, D., \& Hollingsworth, T. D. (2020). How will country-based mitigation measures influence the course of the COVID-19 epidemic? The Lancet, 395(10228), 931-934. doi:10.1016/S0140-6736(20)30567-5

Ashforth, B. E., Kreiner, G. E., \& Fugate, M. (2000). All in a day's work: Boundaries and micro role transitions. Academy of Management Review, 25, 472-491. doi:

10.5465/amr.2000.3363315

Avery, C., \& Zabel, D. (2001). The flexible workplace: A sourcebook of information and research. Westport, CT: Quorum Books.

Ayalon, L. (2020). There is nothing new under the sun: Ageism and intergenerational tension in the age of the COVID-19 outbreak. International Psychogeriatrics, 1-11. https://doi.org/10.1017/S1041610220000575 
Ayalon, L., Chasteen, A., Diehl, M., Levy, B. R., Neupert, S. D., Rothermund, K., ... Wahl, H.W. (2020). Aging in times of the covid-19 pandemic: Avoiding ageism and fostering intergenerational solidarity. The Journals of Gerontology: Series B. https://doi.org/10.1093/geronb/gbaa051

Backman, M. (2020, April 25). Is covid-19 destroying work-life balance? The Motley Fool. Retrieved from: https://www.fool.com/careers/2020/04/25/is-covid-19-destroying-worklife-balance.aspx

Bailenson, J. (2018). Experience on demand. What virtual reality is, how it works, and what it can do. New York: W. W. Norton \& Company.

Bakker, A. B., \& Costa, P. L. (2014). Chronic job burnout and dialy functioning: A theoretical analysis. Burnout Research, 1, 112-119. doi:10.1016/j.burn.2014.04.003

Bakker, A. B., Demerouti, E., \& Sanz-Vergel, A. I. (2014). Burnout and work engagement: The JD-R approach. Annual Review of Organizational Psychology and Organizational Behavior, 1, 389-411. doi:10.1146/annurev-orgpsych-031413-091235

Baltes, P. B., Reese, H. W., \& Lipsitt, L. P. (1980). Life-span developmental psychology. Annual Review of Psychology, 31, 65-110. doi:10.1146/annurev.ps.31.020180.000433

Batalla-Busquets, J. M., \& Martínez-Argüelles, M. J. (2014). Determining factors in online training in companies. The International Journal of Management Education, 12(2), 68-79. doi: 10.1016/j.ijme.2014.01.002

Batt, R., \& Valcour, P. M. (2003). Human resources practices as predictors of work-family outcomes and employee turnover. Industrial Relations, 42, 189-220. doi: 10.1111/1468 232X.00287 
Belsky, J., \& Pluess, M. (2009). Beyond diathesis stress: differential susceptibility to environmental influences. Psychological Bulletin, 135(6), 885-908. doi. 10.1037/a0017376

Benach, J., Vives, A., Amable, M., Vanroelen, C., Tarafa, G., \& Muntaner, C. (2014). Precarious employment: understanding an emerging social determinant of health. Annual Review of Public Health, 35, 229-253. doi: 10.1146/annurev-publhealth-032013-182500

Bhattarai, A., \& Whoriskey, P. (2020, March 9). Companies are putting out hand sanitizer. But for years, many have campaigned against sick pay. The Washington Post. Retrieved from: https://www.washingtonpost.com/business/2020/03/09/sick-leave-coronavirus/

Bliese, P. D., Schepker, D. J., Essman, S. M., \& Ployhart, R. E. (2020). Bridging methodological divides between macro-and microresearch: Endogeneity and methods for panel data. Journal of Management, 46, 70-99. doi:10.1177/0149206319868016

Blustein, D. L., Duffy, R., Ferreira, J. A., Cohen-Scali, V., Cinamon, R. G., \& Allan, B. A. (2020). Unemployment in the time of COVID-19: A research agenda. Journal of Vocational Behavior. doi:10.1016/j.jvb.2020.103436

Bohlmann, C., Rudolph, C. W., \& Zacher, H. (2018). Methodological recommendations to move research on work and aging forward. Work, Aging and Retirement, 4(3), 225-237. doi. 10.1093/workar/wax023

Breuer, C., Hüffmeier, J., \& Hertel, G. (2016). Does trust matter more in virtual teams? A metaanalysis of trust and team effectiveness considering virtuality and documentation as moderators. Journal of Applied Psychology, 101, 1151-1177.

Breuer, C., Hüffmeier, J., Hibben, F., \& Hertel, G. (2019). Trust in teams: A taxonomy of perceived trustworthiness factors and risk-taking behaviors in face-to-face and virtual teams. Human Relations. doi: 10.1177/0018726718818721 
Brewer, A. M. (2000). Work design for flexible scheduling: Barriers and gender implications. Gender, Work, and Organizations, 7(1), 33-44. doi: 10.1111/1468-0432.00091

Brockner, J. (2006). Why it's so hard to be fair. Harvard Business Review, 84(3), 122-129.

Brooks, S. K., Dunn, R., Amlôt, R., Rubin, G. J., \& Greenberg, N. (2018). A systematic, thematic review of social and occupational factors associated with psychological outcomes in healthcare employees during an infectious disease outbreak. Journal of Occupational and Environmental Medicine, 60, 248-257. doi:10.1097/JOM.0000000000001235

Bureau of Labor Statistics (BLS) (2018). Contingent and alternative employment arrangements summary. Retrieved from https://www.bls.gov/news.release/conemp.nr0.htm

Bureau of Labor Statistics (BLS) (2019). Economic News Release. Retrieved from https://www.bls.gov/news.release/atus.t06.htm

Byron, K. (2005). A meta-analytic review of work-family conflict and its antecedents. Journal of Vocational Behavior, 62, 169-198. doi: 10.1016/j.jvb.2004.08.009

Cappelli, P., \& Keller J. (2013). Classifying work in the new economy. Academy of Management Review, 38(4), 575-596. doi: 10.5465/amr.2011.0302

Carlson, D. S., Kacmar, K. M., \& Williams, L. J. (2000). Construction and initial validation of a multidimensional measure of work-family conflict. Journal of Vocational Behavior, 56, 249-276. doi: 10.1006/jvbe.1999.1713

Carlsson, R. [RickCarlsson]. (2020, May 13). This paper is at least interesting in identifying interesting areas and questions that can be investigated through systematic reviews instead of this expert opinion piece. Anyone who thinks this is important should do that and present the evidence for each question. Retrieved from: https://twitter.com/ RickCarlsson/status/1260661040058183681 
Casselman, B., Cohen, P., \& Hsu, T. (2020). 'It's a wreck': 3.3 Million file unemployment claims as economy comes apart. New York Times. https://www.nytimes.com/ 2020/03/26/business/economy/coronavirus-unemployment-claims.html

Centers for Disease Control (2020, March, 16). Severe Outcomes Among Patients with Coronavirus Disease 2019 (COVID-19) — United States, February 12-March 16, 2020. Centers for Disease Control. Retrieved from: https://www.cdc.gov/mmwr/ volumes/69/wr/mm6912e2.htm\#contribAff

Cho, E. (2020). Examining boundaries to understand the impact of COVID-19 on vocational behaviors. Journal of Vocational Behavior. doi:10.1016/j.jvb.2020.103437

Clay, K. (2020, March, 25). Pandemics and the labor market-Then and now. IZA World of Labor. Retrieved from: https://wol.iza.org/opinions/pandemics-and-the-labor-market-thenand-now

Cleary, M., Kornhaber, R., Thapa, D. K., West, S., \& Visentin, D. (2018). The effectiveness of interventions to improve resilience among health professionals: A systematic review. Nurse education today, 71, 247-263. doi:10.1016/j.nedt.2018.10.002

Cohn, S. (2007). After the Black Death: labour legislation and attitudes towards labour in latemedieval western Europe. The Economic History Review, 60(3), 457-485. doi: 10.1111/j.1468-0289.2006.00368.x

Copaken, D. (2020, May 12). I got fired over zoom. The Atlantic. Retrieved from: https://www.theatlantic.com/business/archive/2020/05/fired-zoom-layoffscoronavirus/611509/

Cox, J. (2020a, March 26). Jobless claims soar past 3 million to record high. CNBC. Retrieved from https://www.cnbc.com/2020/03/26/weekly-jobless-claims.html 
Cox, J. (2020b, March 30). Coronavirus job losses could total 47 million, unemployment rate may hit 32\%, Fed estimates. CNBC. Retrieved from: https:/www.cnbc.com/ 2020/03/30/coronavirus-job-losses-could-total-47-million-unemployment-rate-of32percent-fed-says.html

Dai, H., Milkman, K. L., Hofmann, D. A., \& Staats, B. R. (2015). The impact of time at work and time off from work on rule compliance: The case of hand hygiene in health care. Journal of Applied Psychology, 100, 846-862. doi:10.1037/a0038067

Day, D. V., \& Dragoni, L. (2015). Leadership development: An outcome-oriented review based on time and levels of analyses. Annual Review of Organizational Psychology and Organizational Behavior, 2, 133-156. doi:10.1146/annurev-orgpsych-032414-111328

De Boer, J. C., Lok, A., van’t Verlaat, E., Duivenvoorden, H. J., Bakker, A. B., \& Smit, B. J. (2011). Work-related critical incidents in hospital-based health care providers and the risk of post-traumatic stress symptoms, anxiety, and depression: a meta-analysis. Social Science \& Medicine, 73, 316-326. doi:10.1016/j.socscimed.2011.05.009

De Sousa, M. J. C., \& van Dierendonck, D. (2014). Servant leadership and engagement in a merge process under high uncertainty. Journal of Organizational Change Management, 27(6), 877-899. doi:10.1108/JOCM-07-2013-0133

De Witte, H. (2016). On the scarring effects of job insecurity (and how they can be explained). Scandinavian Journal of Work, Environment \& Health, 42(2), 99-102. doi: 10.5271/sjweh.3545

DeRue, D. S., Nahrgang, J. D., Wellman, N., \& Humphrey, S. E. (2011). Trait and behavioral theories of leadership: An integration and meta-analytic test of their relative validity. Personnel Psychology, 64(1), 7-52. doi: 10.1111/j.1744-6570.2010.01201.x 
Dietz, C., Zacher, H., Scheel, T., Otto, K., \& Rigotti, T. (2020). Leaders as role models: Effects of leader presenteeism on employee presenteeism and sick leave. Work \& Stress. doi: $10.1080 / 02678373.2020 .1728420$

Duffy, K. (2020, April 16). What to do: contemplating staffing plans amid an evolving health crisis. Forbes. Retrieved from: https://www.forbes.com/sites/forbeshumanresources council/2020/04/16/what-to-do-contemplating-staffing-plans-amid-an-evolving-healthcrisis/

Eby, L. T., Mitchell, M., \& Zimmerman, L. (2016). Work and family in times of crisis. In T. Allen and L. Eby (Eds.), The Oxford Handbook of Work and Family (pp. 417-430). New York: Oxford Press.

Escrit, T. (2020, March 20). German unemployment could top three million in worst coronavirus case. Reuters. Retrieved from: https://www.reuters.com/article/us-health-coronavirusgermany-labour-mar/german-unemployment-could-top-three-million-in-worstcoronavirus-case-institute-idUSKBN21714A

Ezzedeen, S. R., \& Swiercz, P. M. (2007). Development and initial validation of a cognitivebased work-nonwork conflict scale. Psychological Reports, 100, 979-999. doi: $10.2466 / \mathrm{pr} 0.100 .3 .979-999$

Ferrazzi, K. (2020, April 14). The key to managing teams you can’t see: Make everyone accountable to each other. Fast Company. Retrieved from: https://www.fastcompany. com/90489894/the-key-to-managing-teams-you-cant-see-make-everyone-accountable-toeach-other

Fouad, N. A. (2020). Editor in chief's introduction to essays on the impact of COVID-19 on work and workers. Journal of Vocational Behavior. doi:10.1016/j.jvb.2020.103441 
Freeman, J. (2020, April 7). Pandemics Can Mean Strike Wave. Jacobin. Retrieved from: https://www.jacobinmag.com/2020/04/coronavirus-pandemic-strike-wave-spanish-flu

Freistadt, J., \& Strohschein, L. (2013). Family structure differences in family functioning interactive effects of social capital and family structure. Journal of Family Issues, 34, 952974.

French, K. A., Dumani, S., Allen, T. A., \& Shockley, K. M. (2018). A meta-analysis of workfamily conflict and social support. Psychological Bulletin, 144, 284-314. doi: $10.1037 /$ bul0000120

French, K. A., \& Shockley, K. M. (2020). Formal and informal supports for managing work and family. Current Directions in Psychological Science, 29, 207-216.

Friedman, S. D., \& Westring, A. F. (2020, March 10). How working parents can prepare for coronavirus closures. Harvard Business Review. Retrieved from https://hbr.org/ 2020/03/how-working-parents-can-prepare-for-coronavirus-closures

Gajendran, R. S., \& Harrison, D. A. (2007). The good, the bad, and the unknown about telecommuting: Meta-analysis of psychological mediators and individual consequences. Journal of Applied Psychology, 92, 1524-1541. doi: 10.1037/0021-9010.92.6.1524

Gajendran, R. S., Harrison, D. A., \& Delaney-Klinger, K. (2015). Are telecommuters remotely good citizens? Unpacking telecommuting's effects on performance via i-deals and job resources. Personnel Psychology, 68(2), 353-393. doi: 10.1111/peps.12082

Gates, B. (2020). Responding to Covid-19 - a once-in-a-century pandemic? New England Journal of Medicine, 382(18), 1677-1679. doi: 10.1056/NEJMp2003762

Geister, S., Konradt, U., \& Hertel, G. (2006). Effects of process feedback on motivation, satisfaction and performance in virtual teams. Small Group Research, 37, 459-489. 
Gerpott, F. H., Lehmann-Willenbrock, N., Voelpel, S. C., \& Van Vugt, M. (2019). It's not just what is said, but when it's said: A temporal account of verbal behaviors and emergent leadership in self-managed teams. Academy of Management Journal, 62(3), 717-738. doi:10.5465/amj.2017.0149

Gibson, C. (2020). From 'social distancing' to 'care in connecting': An emerging organizational research agenda for turbulent times. Academy of Management Discoveries. https://doi.org/10.5465/amd.2020.0062

Glikson, E., \& Woolley, A. W. (2020). Human trust in Artificial Intelligence: Review of empirical research. Academy of Management Annals.

Greenhaus, J. H., Allen, T. D., \& Spector, P. E. (2006). Health consequences of work-family conflict: The dark side of the work-family interface. In P. L. Perrewé \& Ganster, D. C. (Eds.), Research in Occupational Stress and Well Being, Volume 6 (pp. 61-98). JAI Press/Elsevier.

Greenhaus, J. H., \& Beutell, N. J. (1985). Sources of conflict between work and family roles. The Academy of Management Review, 10, 76-88. doi: 10.5465/amr.1985.4277352

Gregg, P., \& Tominey, E. (2005). The wage scar from male youth unemployment. Labour Economics, 12(4), 487-509. doi: 10.1016/j.labeco.2005.05.004

Guan, Y., Deng, H., \& Zhou, X. (2020). Understanding the impact of the COVID-19 pandemic on career development: Insights from cultural psychology. Journal of Vocational Behavior. doi:10.1016/j.jvb.2020.103438

Guegan, J., Nelson, J., \& Lubart, T. I. (2017). The relationship between contextual cues in virtual environments and creative processes. Cyberpsychology, Behavior, and Social Networking, $20,202-206$. 
Hall, D. T. (2002). Careers in and out of organizations. SAGE Publications.

Hall, D. T. (2004). The protean career: A quarter-century journey. Journal of Vocational Behavior, 65(1), 1-13. doi: 10.1016/j.jvb.2003.10.006

Haslam, S. A., Reicher, S. D., \& Platow, M. J. (2011). The new psychology of leadership: Identity, influence and power. New York: Psychology Press.

Han, K. M., Chang, J., Won, E., Lee, M. S., \& Ham, B. J. (2017). Precarious employment associated with depressive symptoms and suicidal ideation in adult wage workers. Journal of Affective Disorders, 218, 201-209. doi: 10.1016/j.jad.2017.04.049

Hellgren, J., Sverke, M., \& Isaksson, K. (1999). A two-dimensional approach to job insecurity: Consequences for employee attitudes and well-being. European Journal of Work and Organizational Psychology, 8(2), 179-195. doi: 10.1080/135943299398311

Hertel, G., Geister, S., \& Konradt, U. (2005). Managing virtual teams: A review of current empirical research. Human Resource Management Review, 15, 69-95.

Hertel, G., Konradt, U., \& Orlikowski, B. (2004). Managing distance by interdependence: Goal setting, task interdependence, and team-based rewards in virtual teams. European Journal of Work and Organizational Psychology, 13, 1-28.

Hertel, G., Nohe, C., Wessolowski, K., Meltz, O., Pape, J., Fink, J., \& Hüffmeier, J. (2018). Effort gains in occupational teams - The effects of social competition and social indispensability. Frontiers in Psychology. doi: 10.3389/fpsyg.2018.00769.

Hertel, G., \& Zacher, H. (2018). Managing the aging workforce. In D. S. Ones, N. Anderson, C. Viswesvaran, \& H. K. Sinangil (Eds.), The SAGE handbook of Industrial, Work and Organizational Psychology (2nd ed., Vol. 3, pp. 396-428). Thousand Oaks, CA: Sage. 
Hertel, G., Stone, D., Johnson, R., \& Passmore, J. (2017). The psychology of the Internet at work. In G. Hertel, D. Stone, R. Johnson, \& J. Passmore (Eds.), The Wiley Blackwell Handbook of the Psychology of the Internet at Work (p. 1-18). Chichester: WileyBlackwell.

Hirschi, A. (2012). The career resources model: An integrative framework for career counsellors. British Journal of Guidance \& Counselling, 40(4), 369-383. doi: $10.1080 / 03069885.2012 .700506$

Hirschi, A., Steiner, R., Burmeister, A., \& Johnston, C. S. (2020). A whole-life perspective of sustainable careers: The nature and consequences of nonwork orientations. Journal of Vocational Behavior, 117. doi:10.1016/j.jvb.2019.103319

Hoch, J. E., \& Kozlowski, S. W. (2014). Leading virtual teams: Hierarchical leadership, structural supports, and shared team leadership. Journal of Applied Psychology, 99, 390403. doi: $10.1037 / \mathrm{a} 0030264$

Hornung, S., Rousseau, D. M., \& Glaser, J. (2008). Creating flexible work arrangements through idiosyncratic deals. Journal of Applied Psychology, 93(3), 655-664. doi: 10.1037/00219010.93 .3 .655

Hulin, C. L. (2002). Lessons from industrial and organizational psychology. In J. M. Brett \& F. Drasgow (Eds.), The psychology of work (pp. 19-38). Psychology Press.

IJzerman, H., Lewis, N. A., Jr., Weinstein, N., DeBruine, L. M., Ritchie, S. J., Vazire, S., ... Przybylski, A. K. (2020, April 27). Psychological Science is Not Yet a Crisis-Ready Discipline. doi: 10.31234/osf.io/whds4 Inman, P. (2020, April 29). Half of world's workers 'at immediate risk of losing livelihood due 
to coronavirus. The Guardian. Retrieved from: https:/www.theguardian.com/world/2020 /apr/29/half-of-worlds-workers-at-immediate-risk-of-losing-livelihood-due-tocoronavirus

International Labour Organization. (2020). World employment and social outlook: Trends 2020, Geneva, Switzerland: ILO.

James, E. H., Wooten, L. P., \& Dushek, K. (2011). Crisis management: Informing a new leadership research agenda. Academy of Management Annals, 5(1), 455-493. doi: $10.5465 / 19416520.2011 .589594$

Jacobs, A., Richtel, M., \& Baker, M. (2020, March 19). 'At War With No Ammo': Doctors Say Shortage of Protective Gear Is Dire. The New York Times. Retrieved from: https://www.nytimes.com/2020/03/19/health/coronavirus-masks-shortage.html Jiang, I. (2020, March 31). From Walmart to Burger King's parent company, these 14 retail companies are changing their benefits policies amid the coronavirus pandemic. Retrieved from: https://www.businessinsider.com/coronavirus-changes-walmart-starbucks-employeebenefits-2020-3

Jiang, L., \& Lavaysse, L. M. (2018). Cognitive and affective job insecurity: A meta-analysis and a primary study. Journal of Management, 44(6), 2307-2342. doi:

$10.1177 / 0149206318773853$

Job Quality Index (JQI) (2020). JQI Statement on COVID-19 Impact. Retrieved from: https://www.jobqualityindex.com/

Kalleberg, A. L. (2009). Precarious work, insecure workers: Employment relations in transition. American Sociological Review, 74(1), 1-22. doi: 10.1177/000312240907400101

Kalleberg, A. L., \& Vallas, S. P. (2017). Probing precarious work: Theory, research, and 
politics. In A. Kalleberg \& S. Vallas (Eds.), Precarious work (pp. 1-30). Bingley, UK: Emerald Publishing Limited.

Kantamneni, N. (2020). The impact of the COVID-19 pandemic on marginalized populations in the United States: A research agenda. Journal of Vocational Behavior. doi:10.1016/j.jvb.2020.103439

Katz, L. F., \& Krueger, A. B. (2019). The rise and nature of alternative work arrangements in the United States, 1995-2015. ILR Review, 72(2), 382-416. doi: 10.1177/0019793918820008

Kirkman, B. L., \& Mathieu, J. E. (2005). The dimensions and antecedents of team virtuality. Journal of Management, 31, 700-718.

Kochhar, R. \& Passel, J.S. (2020, May 6). Telework may save U.S. jobs in COVID-19 downturn, especially among college graduates. Pew Research Center. Retrieved from: https://www.pewresearch.org/fact-tank/2020/05/06/telework-may-save-u-s-jobs-in-covid19-downturn-especially-among-college-graduates/

Kossek, E. E., Lautsch, B. A., \& Eaton, S. C. (2006). Telecommuting, control, and boundary management: Correlates of policy use and practice, job control, and work-family effectiveness. Journal of Vocational Behavior, 68, 347-367. doi:

10.1016/j.jvb.2005.07.002

Kramer, A., \& Kramer, K. Z. (2020). The potential impact of the Covid-19 pandemic on occupational status, work from home, and occupational mobility. Journal of Vocational Behavior. doi:10.1016/j.jvb.2020.103442

Lagarde, C. (2020, March 19) Our response to the coronavirus emergency. European Central Bank. Retrieved from: https://www.ecb.europa.eu/press/blog/date/2020/html/ecb.blog 200319 11f421e25e.en.html 
Lai, J., Ma, S., Wang, Y., Cai, Z., Hu, J., Wei, N., ... \& Tan, H. (2020). Factors associated with mental health outcomes among health care workers exposed to Coronavirus disease 2019. JAMA Network Open, 3(3), e203976-e203976.

doi:10.1001/jamanetworkopen.2020.3976

Landers, R. N. (Ed.). (2019). The Cambridge handbook of technology and employee behavior. Cambridge, UK: Cambridge University Press.

Langer, G. (2020, March 27). Coronavirus Impacts: Disrupted Lives, Elevated Stress and Soaring Worry. ABC News. Retrieved from: https://abcnews.go.com/Politics/coronavirusimpacts-disrupted-lives-elevated-stress-soaring-worry/story?id=69812058

Larson, L., \& DeChurch, L. A. (2020). Leading teams in the digital age: Four perspectives on technology and what they mean for leading teams. The Leadership Quarterly, 31(1), 101377. doi:10.1016/j.leaqua.2019.101377

Lee, C., Huang, G. H., \& Ashford, S. J. (2018). Job insecurity and the changing workplace: Recent developments and the future trends in job insecurity research. Annual Review of Organizational Psychology and Organizational Behavior, 5, 335-359. Doi:

\subsection{6/annurev-orgpsych-032117-104651}

Lee, S. M., Kang, W. S., Cho, A.-R., Kim, T., \& Park, J. K. (2018). Psychological impact of the 2015 MERS outbreak on hospital workers and quarantined hemodialysis patients. Comprehensive Psychiatry, 87, 123-127. doi:10.1016/j.comppsych.2018.10.003

Lent, R. W., \& Brown, S. D. (2019). Social cognitive career theory at 25: Empirical status of the interest, choice, and performance models. Journal of Vocational Behavior, 115, Article 103316. doi: 10.1016/j.jvb.2019.06.004 
Lewis, H. (2020, March 19). The Coronavirus Is a Disaster for Feminism. The Atlantic.

Retrieved from https://www.theatlantic.com/international/archive/2020/03/feminismwomens-rights-coronavirus-covid19/608302/

Lindberg, C., Norstrand, P., Munger, M., DeMarsico, C., \& Buscell, P. (2009). Letting go, gaining control: positive deviance and MRSA prevention. Clinical Leader, 2, 60-67.

McGregor, L. \& Doshi, N. (2020, April 9). How to keep your team motivated, remotely. Harvard Business Review. Retrieved from: https://hbr.org/2020/04/how-to-keep-your-teammotivated-remotely

MacDermid Wadsworth, S. M. (2010). Family risk and resilience in the context of war and terrorism. Journal of Marriage and Family, 72, 537-556. doi:10.1111/j.17413737.2010.00717.x

Masten, A. S. (2001). Ordinary Magic: Resilience processes in development. American Psychologist, 56, 227-238. doi: 10.1037/0003-066X.56.3.227

Maunder, R. G., Lancee, W. J., Balderson, K. E., Bennett, J. P., Borgundvaag, B., Evans, S., ... Hunter, J. J. (2006). Long-term psychological and occupational effects of providing hospital healthcare during SARS outbreak. Emerging Infectious Diseases, 12, 1924-1932. doi:10.3201/eid1212.060584

Maynard, M. T., Gilson, L. L., Jones Young, N. C., \& Vartiainen, M. (2017). Virtual teams. In G. Hertel, D. Stone, R. Johnson, \& J. Passmore (Eds.), The Wiley Blackwell Handbook of the Psychology of the Internet at Work (p. 315-346). Chichester: Wiley-Blackwell.

McAlonan, G. M., Lee, A. M., Cheung, V., Cheung, C., Tsang, K. W. T., Sham, P. C., .. . Wong, J. G. W. S. (2007). Immediate and sustained psychological impact of an emerging 
infectious disease outbreak on health care workers. The Canadian Journal of Psychiatry, 52, 241-247. doi:10.1177/070674370705200406

Moore, D., Gamage, B., Bryce, E., Copes, R., Yassi, A., \& Group, B. C. I. R. P. S. (2005).

Protecting health care workers from SARS and other respiratory pathogens: organizational and individual factors that affect adherence to infection control guidelines. American journal of Infection Control, 33, 88-96. doi:10.1016/j.ajic.2004.11.003

Nassif, T. H., Start, A. R., Toblin, R. L., \& Adler, A. B. (2019). Self-reported mindfulness and soldier health following a combat deployment. Psychological trauma: theory, research, practice, and policy, 11, 466-474. doi:10.1037/tra0000413

Nazar, J. (2020, May 8). 8 critical lessons leaders need to emerge from the COVID-19 crisis (And one that will surprise you). Fast Company. Retrieved from: https://www.fastcompany.com/90502230/8-critical-lessons-leaders-need-to-emergefrom-the-covid-19-crisis-and-one-that-will-surprise-you

Nickell, L. A., Crighton, E. J., Tracy, C. S., Al-Enazy, H., Bolaji, Y., Hanjrah, S., . . Upshur, R. E. G. (2004). Psychosocial effects of SARS on hospital staff: survey of a large tertiary care institution. Cmaj, 170, 793-798. doi:10.1053/cmaj.1031077

Nicklin, J. M., Seguin, K., \& Flaherty, S. (2019). Positive work-life outcomes: Exploring selfcompassion and balance. European Journal of Applied Positive Psychology, 3(6), 1-13.

O'Duinn, J. (2018). Distributed teams: The art and practice of working together while physically apart. San Francisco: Release Mechanix.

Paul, K. I., \& Moser, K. (2009). Unemployment impairs mental health: Meta-analyses. Journal of Vocational behavior, 74(3), 264-282. doi: 10.1016/j.jvb.2009.01.001 
Petersen, A. (2020, March 25). The kids are home. You need to work. What do you do? The Wall Street Journal. Retrieved from https://www.wsj.com/articles/the-kids-are-home-you-needto-work-what-do-you-do-11585144182

Platt, J. R. (1964). Strong inference. Science, 146(3642), 347-353.

Raghuram, S., Hill, N. S., Gibbs, J. L., \& Maruping, L. M. (2019). Virtual Work: Bridging Research Clusters. Academy of Management Annals, 13(1), 308-341.

Restubog, S. L. D., Ocampo, A. C. G., \& Wang, L. (2020). Taking control amidst the chaos: Emotion regulation during the COVID-19 pandemic. Journal of Vocational Behavior. doi:10.1016/j.jvb.2020.103440

Richter, M., König, C. J., Koppermann, C., \& Schilling, M. (2016). Displaying fairness while delivering bad news: Testing the effectiveness of organizational bad news training in the layoff context. Journal of Applied Psychology, 101(6), 779-792. doi: 10.1037/ap10000087

Riggs, S. A., \& Riggs, D. S. (2011). Risk and resilience in military families experiencing deployment: The role of the family attachment network. Journal of Family Psychology, 25(5), 675-687. doi:10.1037/a0025286

Roose, K. (2020, March 10). Sorry, but Working From Home Is Overrated. The New York Times. Retrieved from https://www.nytimes.com/2020/03/10/technology/working-fromhome.html

Rousseau, D. M., Ho, V. T., \& Greenberg, J. (2006). I-deals: Idiosyncratic terms in employment relationships. Academy of Management Review, 31(4), 977-994. doi:

10.5465/amr.2006.22527470 
Rudolph, C. W. (2016). Lifespan developmental perspectives on working: a literature review of motivational theories Work, Aging and Retirement, 2(2), 130-158. doi: 10.1093/workar/waw012

Rudolph, C. W., Marcus, J., \& Zacher, H. (2018). Global issues in work and aging. In K. S. Shultz \& G. A. Adams (Eds.), Aging and work in the 21st century (2nd ed., pp. 292-324). New York: Routledge.

Rudolph, C. W., Murphy, L., \& Zacher, H. (2019). A systematic review and critique of research on "healthy leadership". The Leadership Quarterly, 31, doi: 10.1016/j.leaqua.2019.101335

Rudolph, C. W., Rauvola, R. S., \& Zacher, H. (2018). Leadership and generations at work: A critical review. The Leadership Quarterly, 29(1), 44-57. doi:10.1016/j.leaqua.2017.09.004

Rudolph, C. W., \& Zacher, H. (2017). Considering generations from a lifespan developmental perspective. Work, Aging and Retirement, 3(2), 113-129. doi:10.1093/workar/waw019

Rudolph, C. W., \& Zacher, H. (2020a). "The COVID-19 generation”: A cautionary note. Work, Aging \& Retirement. doi: 10.1093/workar/waaa009

Rudolph, C. W. \& Zacher, H. (2020b). COVID-19 and careers: On the futility of generational explanations. Journal of Vocational Behavior. doi:10.1016/j.jvb.2020.103433

Ryan, M. K., Haslam, S. A., Morgenroth, T., Rink, F., Stoker, J., \& Peters, K. (2016). Getting on top of the glass cliff: Reviewing a decade of evidence, explanations, and impact. The Leadership Quarterly, 27(3), 446-455. doi:10.1016/j.leaqua.2015.10.008

Schmillen, A., \& Umkehrer, M. (2017). The scars of youth: Effects of early-career unemployment on future unemployment experience. International Labour Review, 156(34), 465-494. doi: 10.1111/ilr.12079 
Schmitz, R. (2020, April 1). Nearly Half A Million Companies In Germany File For State Funds To Pay Workers. National Public Radio. Retrieved from:

https://www.npr.org/sections/coronavirus-live-updates/2020/04/01/825163403/nearly-halfa-million-companies-in-germany-file-for-state-funds-to-pay-workers

Schnall, P. L., Dobson, M., \& Landsbergis, P. (2016). Globalization, work, and cardiovascular disease. International Journal of Health Services, 46(4), 656-692. doi: $10.1177 / 0020731416664687$

Seibert, S. E., Kraimer, M. L., Holtom, B. C., \& Pierotti, A. J. (2013). Even the best laid plans sometimes go askew: Career self-management processes career shocks, and the decision to pursue graduate education. Journal of Applied Psychology, 98(1), 169-182. doi: $10.1037 / \mathrm{a} 0030882$

Shockley, K. M. (2014). Telecommuting. Society for Industrial and Organizational Psychology White Paper Series. http://www.siop.org/WhitePapers/default.aspx/

Shockley, K. M., \& Allen, T. D. (2010). Investigating the missing link in flexible work arrangement utilization: An individual difference perspective. Journal of Vocational Behavior, 76, 131-142. doi: 10.1016/j.jvb.2009.07.002

Shockley, K. M., \& Allen, T. D. (2015). Deciding between work and family: An episodic approach. Personnel Psychology, 68, 283-318. doi: 10.1111/peps.12077

Shoss, M. K. (2017). Job insecurity: An integrative review and agenda for future research. Journal of Management, 43(6), 1911-1939. doi: 10.1177/0149206317691574

Shultz, K. S. (2003). Bridge employment: Work after retirement. In G. A. Adams \& T.A. Beehr (Eds.), Retirement: Reasons, processes, and results: 214-241. New York: Springer.' 
Sibley, C. G., Greaves, L. M., Satherley, N., Wilson, M. S., Overall, N. C., Lee, C. H. J., . . . Barlow, F. K. (2020). Effects of the COVID-19 pandemic and nationwide lockdown on trust, attitudes towards government, and wellbeing. American Psychologist. doi:10.1037/amp0000662

Singer, N. (2020, May 11). Employers rush to adopt virus screening. The tools may not help much. The New York Times. Retrieved from: https://www.nytimes.com/2020/05/11/ technology/coronavirus-worker-testing-privacy.html

Skarlicki, D. P., Barclay, L. J., \& Pugh, D. S. (2008). When explanations for layoffs are not enough: Employer's integrity as a moderator of the relationship between informational justice and retaliation. Journal of Occupational and Organizational Psychology, 81(1), 123-146. doi: 10.1348/096317907X206848

Smith, L. (2015). Reforming the minimum wage: Toward a psychological perspective. American Psychologist, 70(6), 557. doi: 10.1037/a0039579

Sonnentag, S., Pundt, A., \& Albrecht, A.-G. (2014). Temporal perspectives on job stress. In A. J. Shipp \& Y. Fried (Eds.), Time and work. Volume 1: How time impacts individuals (pp. 111-140). New York, NY: Psychology Press.

Spurk, D., \& Straub, C. (2020). Flexible employment relationships and careers in times of the COVID-19 pandemic. Journal of Vocational Behavior. doi:10.1016/j.jvb.2020.103435

Spinney, L. (2020, March 7). The World Changed Its Approach to Health After the 1918 Flu. Will It After The COVID-19 Outbreak? Time. Retrieved from: https://time.com/5797629/health-1918-flu-epidemic/

Spisak, B. R. (2012). The general age of leadership: Older-looking presidential candidates win elections during war. PLoS ONE, 7(5), e36945. 
Splitter, J. (2020, March 18). COVID-19 And Truck Driver Shortage May Threaten Food Supply Chain. Bloomberg. Retrieved from: https://www.forbes.com/sites/jennysplitter/2020/ 03/18/covid-19-and-truck-driver-shortage-may-threaten-food-supply-chain/\#4e48a02b523e

Spurk, D., Hirschi, A., \& Dries, N. (2019). Antecedents and outcomes of objective versus subjective career success: Competing perspectives and future directions. Journal of Management, 45(1), 35-69. doi: 10.1177/0149206318786563

Spurk, D., Kauffeld, S., Meinecke, A. L., \& Ebner, K. (2015). Why do adaptable people feel less insecure? Indirect effects of career adaptability on job and career insecurity via two types of perceived marketability. Journal of Career Assessment, 24(2), 289-306. doi: $10.1177 / 1069072715580415$

Stam, D., van Knippenberg, D., Wisse, B., \& Nederveen Pieterse, A. (2018). Motivation in words: Promotion-and prevention-oriented leader communication in times of crisis. Journal of Management, 44(7), 2859-2887. doi:10.1177/0149206316654543

Stankiewicz, K. (2020, March 25). Mark Cuban says how companies treat workers during pandemic could define their brand 'for decades'. CNBC. Retrieved from: https://www.cnbc.com/2020/03/25/coronavirus-mark-cuban-warns-against-rushingemployees-back-to-work.html

Sternin, J. (2003). Practice positive deviance for extraordinary social and organizational change. In D. Ulrich, M. Goldsmith, L. Carter, J. Bolt, \& n Smallwood (Eds.) The change champion's Fieldguide, Waltham, MA: Best Practice Institute.

Stockton, A., Kastner, A., \& Appelbaum, B. (2020, March 19). 'If I caught the coronavirus, would you want me making your next meal?' The New York Times. Retrieved from: https://www.nytimes.com/2020/03/19/opinion/mcdonalds-paid-leave-coronavirus.html 
Stoker, J. I., Garretsen, H., \& Soudis, D. (2019). Tightening the leash after a threat: A multi-level event study on leadership behavior following the financial crisis. The Leadership Quarterly, 30(2), 199-214. doi:10.1016/j.leaqua.2018.08.004

Suh, A., Cheung, C. M., Ahuja, M., \& Wagner, C. (2017). Gamification in the workplace: The central role of the aesthetic experience. Journal of Management Information Systems, 34, 268-305.

Tam, C. W. C., Pang, E. P. F., Lam, L. C. W., \& Chiu, H. F. K. (2004). Severe acute respiratory syndrome (SARS) in Hong Kong in 2003: stress and psychological impact among frontline healthcare workers. Psychological Medicine, 34, 1197-1204.

doi:10.1017/S0033291704002247

Tappe, A. (2020, May 7), 1 in 5 American workers has filed for unemployment benefits since mid-March. CNN. Retrieved from: https://www.cnn.com/2020/05/07/economy/ unemployment-benefits-coronavirus/index.html

Taylor, S. (2019). The Psychology of Pandemics: Preparing for the Next Global Outbreak of Infectious Disease. Cambridge Scholars Publishing.

Thielsch, M. T., Meeßen, S. M., \& Hertel, G. (2018). Trust and distrust in information systems at the workplace. PeerJ 6:e5483. https://peerj.com/articles/5483.pdf

Thomas, K. (2020, April 8). UN Report : 400 Million Indian Workers May Sink Deeper into Poverty. The New Leam. Retrieved from: https://henewleam.com/2020/04/un-report-400million-indian-workers-may-sink-deeper-into-poverty/

Trevor, C. O., \& Nyberg, A. J. (2008). Keeping your headcount when all about you are losing theirs: Downsizing, voluntary turnover rates, and the moderating role of HR practices. Academy of Management Journal, 51(2), 259-276. 
Ungar, M. (2017). Which counts more: Differential impact of the environment or differential susceptibility of the individual?. British Journal of Social Work, 47(5), 1279-1289. doi. 10.1093/bjsw/bcw 109

United Nations Department of Economic and Social Affairs (UNDESA) (2015). World Population Prospects: The 2015 Revision. New York, NY: United Nations. Retreived from: https://www.helpage.org/global-agewatch/population-ageing-data/populationageing- map/\#

Van Bavel, J. J., Baicker, K., Boggio, P. S., Capraro, V., Cichocka, A., Cikara, M., ... \& Drury, J. (2020). Using social and behavioural science to support COVID-19 pandemic response. Nature Human Behaviour, 1-12. doi: 10.1038/s41562-020-0884-z

Vander Elst, T., Richter, A., Sverke, M., Näswall, K., De Cuyper, N., \& De Witte, H. (2014). Threat of losing valued job features: The role of perceived control in mediating the effect of qualitative job insecurity on job strain and psychological withdrawal. Work and Stress, 31(4), 1-22. doi: 10.1080/02678373.2014.899651

Vander Elst, T., Van den Broeck, A., De Witte, H., \& De Cuyper, N. (2012). The mediating role of frustration of psychological needs in the relationship between job insecurity and workrelated well-being. Work \& Stress, 26(3), 252-271. doi: 10.1080/02678373.2012.703900

Waldman, D. A., Ramirez, G. G., House, R. J., \& Puranam, P. (2001). Does leadership matter? CEO leadership attributes and profitability under conditions of perceived environmental uncertainty. Academy of Management Journal, 44(1), 134-143. doi:10.5465/3069341

Walker, A. (2005). The emergence of age management in Europe. International Journal of Organisational Behaviour, 10(1), 685-697. 
Withane, K. (2020, March 16). Working Remotely During the Coronavirus (COVID-19). Thrive Global. Retrieved from https://thriveglobal.com/stories/working-remotely-during-thecoronavirus-covid-19/

Wong, S. (2020, March 7). China exports plummet by $17 \%$ as coronavirus takes its toll. Financial Times. Retrieved from: https://www.ft.com/content/248396a6-5f89-11ea-b0ab$339 c 2307 b c d 4$

Wong, T. W., Yau, J. K. Y., Chan, C. L. W., Kwong, R. S. Y., Ho, S. M. Y., Lau, C. C., . . Lit, C. H. (2005). The psychological impact of severe acute respiratory syndrome outbreak on healthcare workers in emergency departments and how they cope. European Journal of Emergency Medicine, 12, 13-18.

Wooten, L. P., \& James, E. H. (2008). Linking crisis management and leadership competencies: The role of human resource development. Advances in Developing Human Resources, 10(3), 352-379. doi:10.1177/1523422308316450

World Health Organization (WHO) (2020, March 11). WHO Director-General's opening remarks at the media briefing on COVID-19. World Health Organization. Retrieved from https://www.

who.int/dg/speeches/detail/who-director-general-s-opening-remarks-at-the-media-briefingon-covid-19---11-march-2020

Wright, P.M., \& McMahan, G.C. (1992). Theoretical perspectives for strategic human resource management. Journal of Management 18, 295-320. doi: 10.1177/014920639201800205

Wright, A. L., Meyer, A. D., Reay, T., \& Staggs, J. (2020). Maintaining places of social inclusion: Ebola and the emergency department. Administrative Science Quarterly. doi: $10.1177 / 0001839220916401$ 
Wright, P. M., \& Ulrich, M. D. (2017). A road well traveled: The past, present, and future journey of strategic human resource management. Annual Review of Organizational Psychology and Organizational Behavior, 4, 45-65.

Wu, J., McCann, A., Collins, K., Harris, R., Huang, J., Almukhtar, K. K., ... Baker, M. (2020, March 17). Coronavirus Map: Tracking the Spread of the Outbreak. New York Times. Retrieved from https://www.nytimes.com/interactive/2020/world/coronavirus-maps.html Yavorsky, J. E., Kamp Dush, C. M., \& Schoppe-Sullivan, S. J. (2015). The production of inequality: The gender division of labor across the transition to parenthood. Journal of Marriage and Family, 77, 662-679. doi: 10.1111/jomf.12189

Yukl, G. (2006). Leadership in organizations (6th ed.). Upper Saddle River, NJ: Prentice Hall. Zatzick, C., Marks, M. L., \& Iverson, R. (2009). Which way should you downsize in a crisis? MIT Sloan Management Review, 51, 79-86. doi: 10.1108/hrmid.2010.04418cad.005

Zhang, Y., Waldman, D. A., Han, Y. L., \& Li, X. B. (2015). Paradoxical leader behaviors in people management: Antecedents and consequences. Academy of Management Journal, 58(2), 538-566. doi:10.5465/amj.2012.0995

Zhou, F., Yu, T., Du, R., Fan, G., Liu, Y., Liu, Z., ... \& Guan, L. (2020). Clinical course and risk factors for mortality of adult inpatients with COVID-19 in Wuhan, China: a retrospective cohort study. The Lancet. Advance online publication.

Zhu, Z., Xu, S., Wang, H., Liu, Z., Wu, J., Li, G., . . Sun, W. (2020). COVID-19 in Wuhan: Immediate Psychological Impact on 5062 Health Workers. medRxiv. doi:10.1101/2020.02.20.20025338

Zikic, J., \& Klehe, U.-C. (2006). Job loss as a blessing in disguise: The role of career exploration 
and career planning in predicting reemployment quality. Journal of Vocational Behavior, 69(3), 391-409. doi: 10.1016/j.jvb.2006.05.007

Zsiros, S. (2020, March 31). Coronavirus in Europe: one million job losses in two weeks is tip of the iceberg. EuroNews. Retrieved from: https://www.euronews.com/2020/03, S./31/coronavirus-in-europe-one-million-job-losses-in-two-weeks-is-tip-of-the-iceberg 
Table 1. Summary of 10 Areas, "Sub-Topics," and Prototypical Headlines

\begin{tabular}{|c|c|c|c|}
\hline Areas & Sub-Topics & $\begin{array}{c}\text { Example Headlines Highlighting } \\
\text { COVID-19 Impacts } \\
\end{array}$ & Citation \\
\hline Occupational Health \& Safety & $\begin{array}{l}\text { - Job stressors \& demands } \\
\text { - Strain \& health outcomes } \\
\text { - Frontline workers }\end{array}$ & $\begin{array}{l}\text { "Employers Rush to Adopt Virus } \\
\text { Screening. The Tools May Not Help } \\
\text { Much" }\end{array}$ & Singer (2020) \\
\hline Work-Family Issues & $\begin{array}{l}\text { - Work-family conflict } \\
\text { - Gender inequities } \\
\text { - Caregiving }\end{array}$ & $\begin{array}{l}\text { "Is COVID-19 Destroying Work-Life } \\
\text { Balance?" }\end{array}$ & Backman (2020) \\
\hline Telework & $\begin{array}{l}\text { - Flextime \& flexplace } \\
\text { - Remote work \& telecommuting } \\
\text { - Boundary management }\end{array}$ & $\begin{array}{l}\text { "Telework may save U.S. jobs in } \\
\text { COVID-19 downturn, especially among } \\
\text { college graduates' }\end{array}$ & Kochhar \& Passel (2020) \\
\hline Virtual Teamwork & $\begin{array}{l}\text { - Virtuality } \\
\text { - Communication technologies } \\
\text { - Virtual collaboration }\end{array}$ & $\begin{array}{l}\text { "The key to managing teams you can't } \\
\text { see: Make everyone accountable to each } \\
\text { other' }\end{array}$ & Ferrazzi (2020) \\
\hline Job Insecurity & $\begin{array}{l}\text { - Quantitative \& qualitative insecurity } \\
\text { - Job loss } \\
\text { - Economic uncertainty }\end{array}$ & "I Got Fired Over Zoom" & Copaken (2020) \\
\hline Precarious Work & $\begin{array}{l}\text { - "Gig" work } \\
\text { - Alternative work arrangements } \\
\text { - Social protections }\end{array}$ & $\begin{array}{l}\text { "Half of world's workers 'at immediate } \\
\text { risk of losing livelihood due to } \\
\text { coronavirus"" }\end{array}$ & Inman (2020) \\
\hline Leadership & $\begin{array}{l}\text { - Crisis leadership } \\
\text { - Leader emergence } \\
\text { - Leadership development } \\
\end{array}$ & $\begin{array}{l}\text { " } 8 \text { critical lessons leaders need to emerge } \\
\text { from the COVID-19 crisis (and one that } \\
\text { will surprise you)" }\end{array}$ & Nazar (2020) \\
\hline HR Policy & $\begin{array}{l}\text { - Operational \& strategic tasks } \\
\text { - Health \& wellness policies } \\
\text { - Training \& upskilling } \\
\end{array}$ & $\begin{array}{l}\text { "What to do: contemplating staffing } \\
\text { plans amid an evolving health crisis" }\end{array}$ & Duffy (2020) \\
\hline The Aging Workforce & $\begin{array}{l}\text { - Age Discrimination } \\
\text { - Retirement } \\
\text { - Differential reactivity \& susceptibility }\end{array}$ & $\begin{array}{l}\text { "COVID-19 has some older workers } \\
\text { rethinking retirement" }\end{array}$ & Adams (2020) \\
\hline Careers & $\begin{array}{l}\text { - Career shocks } \\
\text { - Career counseling \& development } \\
\text { - Career choice }\end{array}$ & $\begin{array}{l}\text { "Finding jobs and building careers in the } \\
\text { age of COVID-19 and } \\
\text { beyond" }\end{array}$ & Abedin (2020) \\
\hline
\end{tabular}


Table 2. Summary of Research and Practice Challenges and Opportunities Associated with COVID-19

\begin{tabular}{|c|c|c|c|c|}
\hline Areas & $\begin{array}{c}\text { Research } \\
\text { Challenges }\end{array}$ & $\begin{array}{c}\text { Research } \\
\text { Opportunities }\end{array}$ & $\begin{array}{c}\text { Practice } \\
\text { Challenges }\end{array}$ & $\begin{array}{c}\text { Practice } \\
\text { Opportunities }\end{array}$ \\
\hline Occupational Health \& Safety & $\begin{array}{l}\text { - How can workers perform } \\
\text { at a high level over a long } \\
\text { period of time, even when } \\
\text { they experience high strain } \\
\text { levels? } \\
\text { - How do job stressors and } \\
\text { strain symptoms develop } \\
\text { over time? } \\
\text { - How can researchers } \\
\text { implement strong research } \\
\text { designs during times of } \\
\text { crises? }\end{array}$ & $\begin{array}{l}\text { - Use objective indicators } \\
\text { (e.g., infectious cases, deaths) } \\
\text { as additional factors in } \\
\text { prediction models. } \\
\text { - Incorporate modules } \\
\text { assessing crisis parameters in } \\
\text { ongoing research projects. }\end{array}$ & $\begin{array}{l}\text { - How to reduce health } \\
\text { care workers' workload } \\
\text { and enable daily recovery } \\
\text { during times with high } \\
\text { case load? } \\
\text { - How to teach health } \\
\text { care workers and other } \\
\text { highly needed personnel } \\
\text { adequate coping } \\
\text { strategies? }\end{array}$ & $\begin{array}{l}\text { - Build on experiences in other } \\
\text { extreme work settings (e.g., } \\
\text { military, bushfire brigades). } \\
\text { - Emphasize a strong safety } \\
\text { climate and provide } \\
\text { organizational support for safety. } \\
\text { - Prepare intervention programs } \\
\text { to be rolled out during and after } \\
\text { the acute crisis in order to } \\
\text { prevent post-traumatic stress } \\
\text { symptoms }\end{array}$ \\
\hline Work-Family Issues & $\begin{array}{l}\text { - How has the pandemic } \\
\text { influenced different forms } \\
\text { of work-family conflict? } \\
\text { - What unique work-family } \\
\text { challenges are faced by } \\
\text { different populations of } \\
\text { workers? } \\
\text { - What is potential positive } \\
\text { work-family outcomes of } \\
\text { the pandemic? }\end{array}$ & $\begin{array}{l}\text { - Develop a more fine- } \\
\text { grained understanding of } \\
\text { work-family struggles during } \\
\text { a crisis situation. } \\
\text { - Explore the intersection of } \\
\text { race/class/gender to improve } \\
\text { understanding of work-family } \\
\text { challenges across a broader } \\
\text { range of employees. } \\
\text { - Apply a variety of } \\
\text { methodologies to gain in- } \\
\text { depth understanding of work- } \\
\text { family dynamics. }\end{array}$ & $\begin{array}{l}\text { - How are existing } \\
\text { national and } \\
\text { organizational policies } \\
\text { able to meet employees' } \\
\text { work-family needs? } \\
\text { - How can organizations } \\
\text { and supervisors best } \\
\text { support employees during } \\
\text { this time? }\end{array}$ & $\begin{array}{l}\text { - Leverage knowledge gained } \\
\text { about work-family struggles } \\
\text { during the pandemic to positively } \\
\text { impact future } \\
\text { national/organizational policies. } \\
\text { - Identify key resources that can } \\
\text { improve employees' work-family } \\
\text { outcomes during crisis situations. }\end{array}$ \\
\hline
\end{tabular}




\begin{tabular}{|c|c|c|c|c|}
\hline Telework & $\begin{array}{l}\text { - How do contextual } \\
\text { variables that vary within } \\
\text { different remote work } \\
\text { arrangements (e.g., use of } \\
\text { different technology, } \\
\text { supervisory styles, } \\
\text { communication techniques) } \\
\text { impact employee well- } \\
\text { being and performance? } \\
\text { - How does forced } \\
\text { telecommuting due to the } \\
\text { pandemic impact long-term } \\
\text { organizational policies and } \\
\text { attitudes toward } \\
\text { telecommuting? } \\
\text { - How can employees with } \\
\text { high segmentation } \\
\text { boundary management } \\
\text { practices best preserve this } \\
\text { preference while } \\
\text { telecommuting? }\end{array}$ & $\begin{array}{l}\text { - Leverage the large } \\
\text { workforce that is now } \\
\text { working remotely across a } \\
\text { wide variety of jobs and } \\
\text { organizational contexts to } \\
\text { study contextual factors. } \\
\text { - Conduct longitudinal } \\
\text { research that retroactively } \\
\text { assesses pre-COVID-19 } \\
\text { organizational policies and } \\
\text { attitudes about face-time } \\
\text { norms and repeat } \\
\text { measurement post-COVID- } \\
19 \text { after the return to standard } \\
\text { work arrangements. } \\
\text { - Conduct qualitative } \\
\text { research on telecommuters' } \\
\text { strategies based on their } \\
\text { boundary management } \\
\text { preferences. }\end{array}$ & $\begin{array}{l}\text { - How can workforce } \\
\text { morale be sustained when } \\
\text { physical interactions are } \\
\text { limited? } \\
\text { - What are best practices } \\
\text { in telecommuting } \\
\text { arrangements to facilitate } \\
\text { worker well-being and } \\
\text { productivity? } \\
\text { - What can organizations } \\
\text { do to cater to individuals } \\
\text { who must work from } \\
\text { home but have children at } \\
\text { home? }\end{array}$ & $\begin{array}{l}\text { - Provide opportunities for } \\
\text { workers to still connect through } \\
\text { virtual coffee breaks or happy } \\
\text { hours. Allow time in virtual } \\
\text { meetings for some socialization. } \\
\text { - Review existing empirical } \\
\text { evidence and gather data from } \\
\text { this forced telecommuting time } \\
\text { to better understand what works } \\
\text { and what does not. } \\
\text { - Prepare policies that allow for } \\
\text { reduced hours schedules or } \\
\text { temporary leave to accommodate } \\
\text { crisis situations for those who } \\
\text { simply cannot be as productive at } \\
\text { home. }\end{array}$ \\
\hline
\end{tabular}




\begin{tabular}{|c|c|c|c|c|}
\hline Virtual Teamwork & $\begin{array}{l}\text { - Which features of virtual } \\
\text { teamwork are particularly } \\
\text { helpful in a pandemic? } \\
\text { - How can specific demands } \\
\text { of a pandemic guide use(r)- } \\
\text { inspired development of } \\
\text { virtual teamwork tools? } \\
\text { - How can emerging } \\
\text { technologies (Virtual } \\
\text { Reality, automated } \\
\text { feedback routines, etc.) } \\
\text { support team members' } \\
\text { needs in a pandemic? }\end{array}$ & $\begin{array}{l}\text { - Use the current crisis as a } \\
\text { motivation for innovation and } \\
\text { empirical research on virtual } \\
\text { teamwork. } \\
\text { - Examine teamwork } \\
\text { processes when projects have } \\
\text { to go virtual rapidly. } \\
\text { - Support and leverage open } \\
\text { exchange on innovative } \\
\text { teamwork solutions within } \\
\text { and across organizations and } \\
\text { industries. }\end{array}$ & $\begin{array}{l}\text { - How can ongoing teams } \\
\text { and projects be digitized? } \\
\text { - How can teams stay } \\
\text { connected, motivated, } \\
\text { and maintain high team } \\
\text { spirit despite spatial } \\
\text { dispersion? } \\
\text { - How can } \\
\text { technologically less } \\
\text { experienced workers be } \\
\text { prepared for virtual } \\
\text { teamwork? }\end{array}$ & $\begin{array}{l}\text { - Implement and further develop } \\
\text { virtual teamwork for physical } \\
\text { distancing and social connection } \\
\text { during a pandemic. } \\
\text { - Use the pandemic crisis to } \\
\text { rethink what really matters in } \\
\text { teams: Purposeful tasks, mutual } \\
\text { support, and positive recognition. } \\
\text { - Consider lessons learned and } \\
\text { successful teamwork solutions } \\
\text { from the current pandemic for } \\
\text { implementation and maintenance } \\
\text { after the crisis. }\end{array}$ \\
\hline & $\begin{array}{l}\text { - How can environmental } \\
\text { implications of virtual } \\
\text { teamwork be considered for } \\
\text { far-sighted planning and } \\
\text { training? }\end{array}$ & & $\begin{array}{l}\text { - How can health and } \\
\text { security issues be } \\
\text { maintained when team } \\
\text { members work remotely? }\end{array}$ & \\
\hline Job Insecurity & $\begin{array}{l}\text { - How has the pandemic } \\
\text { shaped employees' job } \\
\text { insecurity experiences? } \\
\text { - What are the short- and } \\
\text { long-term consequences of } \\
\text { the high levels of job } \\
\text { insecurity experienced } \\
\text { around the world? } \\
\text { - How do the conditions } \\
\text { surrounding job insecurity } \\
\text { impact whether employees } \\
\text { return to/remain with their } \\
\text { employers after the crisis is } \\
\text { over? }\end{array}$ & $\begin{array}{l}\text { - Develop a more nuanced } \\
\text { understanding of job } \\
\text { insecurity experiences. } \\
\text { - Study the pandemic as a } \\
\text { natural experiment that has } \\
\text { created high levels of job } \\
\text { insecurity. } \\
\text { - Expand our understanding } \\
\text { of individual and collective } \\
\text { outcomes of job insecurity. }\end{array}$ & $\begin{array}{l}\text { - What strategies can } \\
\text { organizations use to } \\
\text { manage uncertainty } \\
\text { during this inherently } \\
\text { uncertain time? } \\
\text { - How can organizations } \\
\text { mitigate the negative } \\
\text { consequences of job } \\
\text { insecurity and, for those } \\
\text { employees ultimately } \\
\text { laid-off/furloughed, } \\
\text { achieve a positive } \\
\text { transition back to work? }\end{array}$ & $\begin{array}{l}\text { - Crisis offers an opportunity for } \\
\text { organizations to demonstrate } \\
\text { support for their employees and } \\
\text { build loyalty. } \\
\text { - Employers and employees may } \\
\text { benefit from strategies that help } \\
\text { employees to maintain social } \\
\text { connection, identity, meaning, } \\
\text { and skill development despite } \\
\text { actual or potential job loss. }\end{array}$ \\
\hline
\end{tabular}




\begin{tabular}{|c|c|c|c|c|}
\hline Precarious Work & $\begin{array}{l}\text { - What does the pandemic } \\
\text { reveal about existing } \\
\text { inequities within the labor } \\
\text { market and how does it } \\
\text { exacerbate these inequities? } \\
\text { - Are people with } \\
\text { precarious work more } \\
\text { vulnerable to the economic } \\
\text { and health effects of the } \\
\text { pandemic? } \\
\text { - What are factors that help } \\
\text { people with precarious } \\
\text { work cope with crises? }\end{array}$ & $\begin{array}{l}\text { - Examine how the pandemic } \\
\text { exacerbates existing } \\
\text { inequities in access to power } \\
\text { and resources. } \\
\text { - Investigate the extent to } \\
\text { which precarious work is a } \\
\text { risk factor for the financial } \\
\text { and health consequences of } \\
\text { the pandemic. } \\
\text {-Evaluate which } \\
\text { interventions and policies are } \\
\text { most effective at alleviating } \\
\text { the consequences of the } \\
\text { pandemic for people with } \\
\text { precarious work. }\end{array}$ & $\begin{array}{l}\text {-How can organizations } \\
\text { minimize precarity in } \\
\text { their workforce while } \\
\text { also maintaining } \\
\text { competitiveness and } \\
\text { productivity? } \\
\text {-How can organizations } \\
\text { and governments } \\
\text { effectively support people } \\
\text { with precarious work } \\
\text { through the pandemic? } \\
\text {-What interventions and } \\
\text { policies will help people } \\
\text { with precarious work } \\
\text { through the pandemic and } \\
\text { other crises? }\end{array}$ & $\begin{array}{l}\text {-Expand access to benefits within } \\
\text { organizations to part-time and } \\
\text { temporary employees to increase } \\
\text { retention and productivity. } \\
\text {-Consider precarious work as a } \\
\text { potential risk factor for the } \\
\text { economic and health } \\
\text { consequences of COVID-19. } \\
\text {-Develop and implement long- } \\
\text { term governmental policies (e.g., } \\
\text { a living wage, expanded } \\
\text { employment insurance) that } \\
\text { support people with precarious } \\
\text { work through personal and larger } \\
\text { scale crises. }\end{array}$ \\
\hline Leadership & $\begin{array}{l}\text { - How does the pandemic } \\
\text { influence leadership? } \\
\text { - Who emerges as a leader } \\
\text { during the pandemic? } \\
\text { - What makes leaders } \\
\text { effective during the } \\
\text { pandemic? }\end{array}$ & $\begin{array}{l}\text { - Examine the pandemic as a } \\
\text { context factor that leads to } \\
\text { changes in leadership. } \\
\text { - Study individual differences } \\
\text { and behaviors that impact } \\
\text { leader emergence during the } \\
\text { pandemic. } \\
\text { - Study what effective leaders } \\
\text { actually "do" in different } \\
\text { phases of a crisis. }\end{array}$ & $\begin{array}{l}\text { - Which leaders can deal } \\
\text { successfully with the } \\
\text { demands (e.g., insecurity) } \\
\text { during the pandemic? } \\
\text { - How can leaders be } \\
\text { trained to deal with a } \\
\text { crisis situation? } \\
\text { - How do leaders' health- } \\
\text { related behaviors impact } \\
\text { on themselves and their } \\
\text { followers? }\end{array}$ & $\begin{array}{l}\text { - Select leaders for and train } \\
\text { them in digital/e-leadership } \\
\text { knowledge, skills, and abilities. } \\
\text { - Improve leaders and followers' } \\
\text { health-related attitudes, values, } \\
\text { and behaviors. }\end{array}$ \\
\hline
\end{tabular}




\begin{tabular}{|c|c|c|c|c|}
\hline HR Policy & $\begin{array}{l}\text { - Does the pandemic affect } \\
\text { strategic and operational } \\
\text { HR policies in companies? } \\
\text { - Do HR-featured } \\
\text { idiosyncratic deals (I-deals) } \\
\text { help employees to better } \\
\text { cope with the COVID-19 } \\
\text { related work situation? } \\
\text { - What are downsizing } \\
\text { strategies that do not } \\
\text { destroy talent resources and } \\
\text { motivation of remaining } \\
\text { employees? }\end{array}$ & $\begin{array}{l}\text { - Examine development and } \\
\text { the role of HR policies during } \\
\text { the pandemic. } \\
\text { - Investigate employee } \\
\text { perceptions and effectiveness } \\
\text { of I-deals during the } \\
\text { pandemic. } \\
\text { - Evaluate the effectiveness } \\
\text { of different downsizing } \\
\text { strategies. }\end{array}$ & $\begin{array}{l}\text {-How can HR polices } \\
\text { help to build a new } \\
\text { hygiene culture in } \\
\text { organizations? } \\
\text { - How can companies } \\
\text { sustain and develop talent } \\
\text { during the pandemic? } \\
\text {-What is a commitment- } \\
\text { oriented downsizing } \\
\text { strategy during a } \\
\text { pandemic? }\end{array}$ & $\begin{array}{l}\text { - Learn from practice in public } \\
\text { health research, like positive } \\
\text { deviance procedures. } \\
\text { - Invest in digital and blended- } \\
\text { learning activities to develop } \\
\text { talent resources. } \\
\text { '- Have an open and transparent } \\
\text { communication about } \\
\text { downsizing and use involuntary } \\
\text { lay-offs. }\end{array}$ \\
\hline The Aging Workforce & $\begin{array}{l}\text { - How are workers of } \\
\text { different ages differentially } \\
\text { affected by the pandemic? } \\
\text { - Are older workers more or } \\
\text { less susceptible to the } \\
\text { environmental challenges } \\
\text { associated with COVID-19? }\end{array}$ & $\begin{array}{l}\text { - Examine age as a "risk } \\
\text { factor" for the influence of } \\
\text { COVID-19-related changes } \\
\text { to work. } \\
\text { - Examine features of work } \\
\text { and work environments that } \\
\text { support workers of different } \\
\text { ages. }\end{array}$ & $\begin{array}{l}\text { - How can organizations } \\
\text { tailor policies to help } \\
\text { workers of all ages } \\
\text { manage the financial and } \\
\text { psycho-social "fallout" of } \\
\text { COVID-19? }\end{array}$ & $\begin{array}{l}\text { - Tailor policies (e.g., retirement } \\
\text { schemes) to optimize challenges } \\
\text { faced by workers of different } \\
\text { ages as a result of the pandemic. }\end{array}$ \\
\hline Careers & $\begin{array}{l}\text { - How does the pandemic } \\
\text { affect career trajectories? } \\
\text { - How are career choices of } \\
\text { students affected by the } \\
\text { pandemic? } \\
\text { - In what way do people's } \\
\text { career attitudes change due } \\
\text { to the crisis? }\end{array}$ & $\begin{array}{l}\text { - Examine how people } \\
\text { change careers voluntarily or } \\
\text { involuntarily due to the crisis. } \\
\text { - Study if and how people } \\
\text { develop new career } \\
\text { motivations. } \\
\text { - Investigate which personal } \\
\text { and contextual career } \\
\text { resources help people dealing } \\
\text { effectively with the career } \\
\text { shock of the pandemic. }\end{array}$ & $\begin{array}{l}\text { - How can businesses } \\
\text { and employees be } \\
\text { supported to minimize } \\
\text { negative effects on future } \\
\text { career trajectories and } \\
\text { progression? } \\
\text { - How can employees and } \\
\text { the unemployed be } \\
\text { optimally supported in } \\
\text { dealing with career } \\
\text { insecurity due to the } \\
\text { crisis? }\end{array}$ & $\begin{array}{l}\text { - Use volunteering as a way to } \\
\text { increase career resources and } \\
\text { work meaningfulness. } \\
\text { - Help clients in career } \\
\text { counseling to adopt a whole-life } \\
\text { perspective in their career self- } \\
\text { management. }\end{array}$ \\
\hline
\end{tabular}

